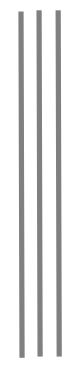

\title{
Pandemi Sürecinde Uzaktan Eğitim ile Okul Öncesi Eğitimden ilkokula Geçiş Hakkında Veli Görüşleri
}

\author{
Ahmet Sami KONCA', Tuğba ÇAKIR ${ }^{2}$
}

\begin{abstract}
Öz: Bu araştırmanın amacı pandemi sürecinde uzaktan eğitim ile okul öncesinden ilkokula geçiş hakkında veli görüşlerini belirlemektir. Nitel araştırma desenlerinden durum çalışması deseninde tasarlanan araştırmanın katılımcıları çocuğu pandemi döneminde okul öncesi eğitimi tamamlayıp ilkokul 1.sınıfa geçiş yapan 20 veliden oluşmaktadır. Veri toplamak amacıyla katılımcılarla yarı yapılandırılmış görüşmeler gerçekleştirilmiştir. Araştırmadan elde edilen sonuçlara göre pandemi başlangıcında çocukların okul öncesi eğitime katılamadığı ve velilerin yapılan uzaktan eğitimden memnun olmadıkları, uzaktan eğitim ile yapılan okul öncesi eğitimde ise çoğunlukla öğretmenlerin telefon üzerinden WhatsApp uygulaması aracılığıyla etkinlikler gönderdiği, bunun yanında velilerin de kendi oluşturduğu etkinlikleri kullandıkları, süreçte aileye düşen görevlerin arttığı, çocukların iletişim, eğitsel ve sosyal açıdan çeşitli sıkıntılar yaşadıkları belirlenmiştir. İlkokul başlangıcında uzaktan eğitim sürecinde en çok EBA (Eğitim Bilişim Ağı) ve Zoom uygulamalarının kullanıldığı en az ise TRT Okul kanalının tercih edildiği bulunmuştur. Veliler senkron ve asenkron olarak katılım gösterdikleri uzaktan eğitim sürecinde yaşadıkları çeşitli olumlu durumlardan ayrıca sorun ve önerilerden bahsetmişlerdir. Araştırmanın sonuçları doğrultusunda pandemi döneminde okul öncesi eğitimin göz ard1 edilmemesi ve öğretmen ile öğrenci arasında iletişimin artırılması önerilmektedir.
\end{abstract}

Anahtar Sözcükler: İlkokula geçiş, Uzaktan eğitim, Okul öncesi eğitim, Pandemi

\section{Investigation of Parents' Views on Distance Education of Children's Transition from Preschool Education to Primary School During the Pandemic Process}

\begin{abstract}
This study aimed to determine the parents' views about the transition from preschool to primary school with distance education during the pandemic process. The participants of the study, which was designed as a case study, consisted of 20 parents whose children completed preschool education during the pandemic period and transferred to the 1st grade of primary school. Data was collected by conducting semi-structured interviews with the participants. Results of the study showed that preschool children couldn't attend early childhood education and parents of preschool children were not satisfied from the distance education, preschool teachers sent activities over their smartphones through WhatsApp application, as well as the parents' duties in the process of using the activities they created, the children have various communication, educational and social problems. At the primary school level, parents talked about the various positive situations they experienced in the distance education process as well as problems and suggestions. In line with the results of the research, early childhood education shouldn't be overlooked during pandemic, and effective communication between teacher and student should be increased.
\end{abstract}

Keywords: Transition to primary school, Distance education, Preschool education, Pandemic 
Aralık-2019'da Çin Halk Cumhuriyeti'nde henüz nedeni bilinmeyen bir şekilde ortaya çıan SAR-CoV-2 virüsünün bulaşma oranı 2020 yılı ocak ayında iyice artmış ve diğer ülkelerde de görülmeye başlamıştır. Süreç içinde tüm dünyaya yayılan yeni tip korona virüsün (COVID-19) Dünya Sağlık Örgütü (DSÖ) tarafından pandemiye dönüştüğü duyurulmuştur (DSÖ, 2020). Bunun üzerine tüm dünya ülkeleri, kendilerini korumak için salgına yönelik olarak çeşitli tedbirler almaya veya farklı uygulamalara yönelmiştir. Ancak bu süreçte en fazla etkilenen alanlar ekonomi ve eğitim olmuştur. Bu farklı uygulamalardan biri de eğitim alanında olmuştur. Çünkü virüsün hastalığa dönüşerek bulaşının artması neticesinde ülkeler yüz yüze eğitime ara verme kararı alarak okulları kapatmışlardır (Sönmez, Yıldırım ve Çetinkaya, 2020). Eğitim öğretim faaliyetlerine kesintisiz devam edebilmek ve çocukların eğitimden geri kalmalarını önleyebilmek için uzaktan eğitime geçilmesi kaçınılmaz olmuştur. Bu olağan dışı pandemi döneminde eğitim-öğretim faaliyetlerine hızlı ve güvenilir bir şekilde ulaşılmak amaçlanmıştır (Hodges, Moore, Lockee, Trust ve Bond, 2020). Örneğin, Çin Halk Cumhuriyeti Eğitim Bakanlığı ile Bilgi Teknolojileri Bakanlığı ortak bir çalışmayla öğretmen ve öğrencilere çeşitli çevrimiçi platform seçenekleri sunmuşlardır (Xie ve Yang, 2020). Çekya'da ise televizyon ve internet üzerinden uzaktan eğitim süreci başlatılmış, ilkokul kademesindeki çocuklar günde 2-4 saat arasında uzaktan eğitime katılmışlardır (Brom ve diğerleri, 2020).

Dünyada olduğu gibi ülkemizde de pandemi döneminde eğitim alanında çeşitli değişiklikler yapma zorunluluğu doğmuştur. İlk vakanın görülmesinden itibaren eğitime kısa süreli olarak ara verilmiş fakat vaka artışının devam etmesi nedeniyle 23 Mart 2020 tarihinde Mili Eğitim Bakanlığı (MEB) yüz yüze eğitime belirsiz bir süre ara verildiğini, bu süreçte çocukların eğitimden geri kalmaması için de uzaktan eğitime geçildiğini duyurmuştur (Özdoğan ve Berkant, 2020). Tüm eğitim kademelerinin uzaktan eğitime geçmesiyle birlikte MEB uzaktan eğitim uygulamalarını öğretmen, öğrenci ve velilerle paylaşmıştır. 2019-2020 eğitim öğretim yılının uzaktan eğitimle tamamlanmasıyla birlikte 2020-2021 eğitim öğretim yılı da pandemi koşullarının devam etmesinden dolayı ağırlıklı olarak uzaktan eğitime devam edilmiştir. Ancak, pandemi nedeniyle yaşanan hızlı ve beklenmedik değişiklik eğitimin tüm paydaşlarını etkilemiştir.

Bu sürece erken çocukluk eğitimi bağlamında bakıldığında, pandemi başlangıcında okul öncesi eğitime devam eden öğrencilerin bir kısmı uzaktan eğitim ile dönemi tamamlayarak ilkokula geçiş süreci yaşarken öğrencilerin diğer kısmı ise okul öncesi eğitimi pandemi başlangıcında noktalamış ve diğer dönem ilkokula başlamışlardır. Pandemi döneminde 1. sınıfa başlayan çocuklar belirli aralıklarla yüz yüze eğitime katılsalar da 2020-2021 eğitim öğretim yılının büyük bir kısmını uzaktan eğitim ile geçirmişlerdir. Bilindiği gibi, okul öncesi eğitimden ilkokula geçiş süreci, öğrencilerin gelecekteki davranışlarını ve başarılarını etkileyen önemli bir süreçtir (Dockett ve Perry, 2001). Nitelikli bir okul öncesi eğitimi alan çocukların sosyal uyumları, bilişsel, duyuşsal ve psikomotor gelişimleri aldıkları nitelikli eğitim ile doğru orantılı olarak artmaktadır (Erkan ve Kırca, 2010; Metin ve Aral, 2016). Ayrıca, erken çocukluk döneminde alınan kaliteli eğitimin yetişkinlik döneminde de yaşam çıtıları üzerinde olumlu etkilerinin olduğu yapılan çalışmalarda belirtilmiştir (Currie ve Almond, 2011; Heckman, Pinto ve Savelyev, 2013). Okul öncesi eğitimi, yetişkinlik döneminde de bireyin kişilik yapısını, alışkanlıklarını, değer ve inançlarını etkilemektedir (Oktay, 2003). Okulun ilk yılında zorluk çeken öğrencilerin diğer yıllarda da çeşitli problemler yaşadıkları çeşitli araştırmalarda ortaya konulmuştur (Rice ve O'Brien, 1993). Okul öncesi eğitime devam eden çocukların problemli davranışları, öğretmen ilişkileri ve sosyal becerileri açısından ilköğretime başladıklarında nasıl şekilleneceği üzerine Skalická, Belsky, Stenseng ve Wichstrøm'ın (2015) yaptıkları bir çalışmada , okul öncesi dönemde öğretmenleri ile az yakınlık kuran ve sosyal sorunları olan çocukların ilköğretimde öğretmenleri ile daha çok çatışma yaşadıkları, bununla birlikte okul öncesinde görülen problemli davranışların ilköğretim döneminde devam ettiği belirtilmiştir.

Okul öncesi dönem, çocuklar adına birçok problemin belirlenmesi ve çözümlenmesi açısından değerlidir. Pandemi döneminde uzaktan eğitimle okul öncesi eğitimi tamamlayıp ilkokula geçen çocukların bu duruma bağlı olarak çeşitli engellerle karşılaşmamaları için önemlidir. Bu çalışmada pandemi sürecinde okul öncesi eğitimi tamamlayıp ilkokula geçiş yapan öğrencilerin yaşadıkları sürece odaklanılmıştır. Bu doğrultuda öğrenci velilerinin uzaktan eğitimle ilkokula geçiş süreci hakkında görüşlerinin incelenmesi amaçlanmıştır. 


\section{Pandemi ve Uzaktan Eğitim}

Yüz yüze eğitimin yapılamadığı salgın sürecinde eğitim öğretim faaliyetlerinin devam edebilmesi için bir alternatif olan öğretmen ve öğrencinin farklı mekanlarda olduğu, aynı veya farklı zamanlarda çeşitli araç gereçlerden yararlanarak iletişimin sağlanabildiği eğitim türüne uzaktan eğitim denilmektedir (Türker ve Dündar, 2020). Bir başka ifadeyle, öğrencilere daha az özerklik ve daha çok esneklik sunarak önceden hazırlanan içeriklere ulaşmayı sağlayan bir öğretim modelidir. Ayrıca doğrudan öğretmen ile temas kurarak daha az esneklik sağlayan öğretmen liderliğinde gerçekleşen öğrenme deneyimleridir (Johnston, 2020). Uzaktan eğitim pandemi öncesinde yüz yüze olan eğitimi destekleyici ve tamamlayıcı olarak kullanılıyorken, pandemi süreci ile yapılamayan yüz yüze eğitimin tek alternatifi haline gelmiştir (Türker ve Dündar, 2020). Ayrıca kullanılan yöntem ve teknoloji bağlamında kaliteli yapılan uzaktan eğitimin yüz yüze eğitim ile eşit seviyede veya daha fazla etkili olacağı çeşitli araştırmalarda vurgulanmıştır (Chang ve Satako, 2020). Pandemi sürecinde bilginin taşınması ve dağıtılmasında çevrim içi ve çevrimdışı teknolojilerin kullanılması uzaktan eğitimin dijital ortamlara aktarılmasını kolaylaştırmıştır. Pandemi sebebi ile birçok ülkede uzaktan eğitim için canlı dersler, televizyon ve radyo yayınları ile internet tabanlı çevrimiçi platformlar kullanılmıştır (Chang ve Satako, 2020). Ülkemizde ise uzaktan eğitim için yaygın kullanılan uygulamalar arasında çevrimiçi öğrenme ortamları ve televizyon ile öğretim uygulamaları görülmektedir (Can, 2020).

Türkiye salgın sürecinde aldığı tedbirler kapsamında yüz yüze eğitimin sakıncalı olacağı gerekçesi ile acil uzaktan eğitime geçiş yapmıştır (Tarlakazan ve Tarlakazan 2020). Bu kapsamda ülkemizde MEB tarafından çeşitli dijital platformlar oluşturulmuş veya var olan platformların içerikleri zenginleştirilerek yenilenmiştir. MEB, salgın döneminde eğitimin aksamaması, eğitimde sürekliliğin sağlanması ve bu sancılı süreçte eğitim faaliyetlerine bütün öğrencilerin ulaşabilmesi için uzaktan eğitim kapsamında tüm kademelerdeki öğrencileri kapsayacak şekilde çeşitli çevrimiçi ve çevrimdışı platformlar hazırlamıştır. Eğitim Bilişim Ağı (EBA), televizyon yayınları (TRT Okul, TRT EBA) ve sanal canlı derslere olanak sağlayan uzaktan eğitim platformları ile sanal sınıf uygulamaları şeklinde gerçekleştirilmeye başlanmıştır (Kaynar, Kurnaz, Doğrukök ve Barışık, 2020).

Pandemi döneminde halihazırda var olan, 2011 yılında Fatih (Fırsatları Artırma ve Teknolojiyi İyileştirme Hareketi) projesi kapsamında eğitsel e-içerik oluşturmak amacıyla geliştirilen, ücretsiz olarak eğitimcilerin ve öğrencilerin kullanımına sunulan çevrimiçi sosyal eğitim platformu olan Eğitim Bilişim Ağı (EBA)'nın kullanılması ile uzaktan eğitimde önemli bir başlangıç yapılmıştır (Coşkunserçe ve İşçitürk, 2019). EBA bu süreçte öğrenci, öğretmen ve velilerin kolaylıkla erişebileceği güvenli bir platform olarak çeşitli eğitici içerikler sağlamaktadır (Sönmez ve diğerleri, 2020). Talim ve Terbiye Kurulu tarafından hazırlanan ders içerikleri ve ders kitapları, videolu ders anlatımları, çeşitli görseller, ders dokümanları, sesli hikayeler, yardımcı ders araç gereçleri ve eğitici oyunlar gibi çeşitli içerikler EBA'da yer bulmaktadır (Coşkunserçe ve İşçitürk, 2019). Bunlara ek olarak MEB, uzaktan eğitime geçildiğini açıklamasının ardından EBA içeriğini müfredat kapsamında daha da zenginleştirerek yeni konu ve ders anlatım videoları eklemiştir. Bunun yanında salgın sürecinde fırsat eşitliği kapsamında imkânı olmadığı için internet üzerinden EBA uygulamasına erişemeyen öğrencilerin eğitimden mahrum kalmamaları için TRT ile iş birliği yapılarak çeşitli kademelerde EBA TV kanalları açılmıştır. Bu kanallarda ilkokul, ortaokul ve lise müfredatlarına bağlı olarak ders içerikleri hazırlanmıştır (Demir ve Özdaş, 2020). EBA TV kanalları ile öğrenciler kendi sınıf seviyelerine uygun hazırlanan ders anlatımlarının zamanlarını kanal üzerinde verilen yayın akışından takip ederek derslerine devam edebilmişlerdir (Türker ve Dündar, 2020). TRT, EBA kanalları yanında TRT Okul ve TRT Çocuk kanalları da televizyon üzerinden çeşitli eğitici yayınlar yaparak öğrencilere uzaktan eğitim sürecinde yardımcı olmaya çalışmaktadırlar.

Uzaktan eğitim sürecinde etkin olarak kullanılan diğer uygulamalara bakıldığında ise canlı sınıf uygulamaları ön plana çıkmaktadır. Millî Eğitim Bakanlı̆̆ı öğretmenlere EBA Canlı Ders uygulaması, Zoom ve Skype gibi çeşitli uygulamaları önererek canlı dersler oluşturulabileceğini açıklamıştır (MEB, 2020a). Bu uygulamalar ile öğretmen ve öğrenciler internet üzerinden önceden belirlenen bir saatte bir araya gelerek eş zamanlı ve sanal olarak canlı bir sınıfta ders işlemektedirler. Senkron (eş zamanlı) olarak yapılan bu uzaktan eğitim sayesinde öğretmen ve öğrencilerin karşılıklı ders içi etkileşimlerinin artması sağlanmaktadır (Demir 
ve Özdaş, 2020). Halihazırda var olan EBA uygulaması üzerinden canlı sınıf uygulamaları yapılarak öğrenciler ile karşılıklı ders işleme imkânı verilmektedir. Öğrenciler EBA üzerinden öğretmenin belirlediği saatlerde derse girebilmekte aynı zamanda EBA platformu üzerinde bulunan videolar, görseller gibi içeriklerden yararlanarak dersleri takip edebilmektedirler. Sanal sınıf oluşturmak için en çok kullanılan diğer bir yöntem ise ZOOM uygulamasıdır. Bu uygulama ile hazırlanan oturumlarda sanal dersler işlenerek kayıt altına alınabilmektedir. Ayrıca canlı dersler sırasında ses, görüntü-ekran paylaşımları ve mesajlaşmalar öğretmen ve öğrenciler tarafından kullanılabilmektedir (Çubukçu ve Aktürk, 2020).

Ülkemizde pandeminin ortaya çıkmasıyla birlikte uzaktan eğitime yönelik çalışmalar yoğunluk kazanmasına rağmen çeşitli sorunlar gündeme gelmiştir. 1,5 milyon öğrencinin uzaktan eğitime erişmekte sorun yaşadığı ve öğrencilerin yaklaşık \%8'inin uzaktan eğitime hiç ulaşamadığı Milli Eğitim Bakanı Ziya Selçuk tarafından ifade edilmiştir (Milliyet, 2020). Bunun yanında Millî Eğitim Bakanlığı'nın uzaktan eğitim sürecini izlemek ve değerlendirmek için yayınlamış olduğu Küresel Salgın Döneminde Uzaktan Eğitim Raporu'na göre araştırmaya katılan öğrencilerin \%24'ünün derslere katılmadığı ve bu oranın devlet okulunda okuyan yaklaşık 3,5 milyon öğrenciye tekabül ettiği belirtilmiştir. (MEB, 2020b).

Pandemi döneminde yapılan uzaktan eğitim sadece öğrencilerin derslere katılımını etkileyen bir durum olmamıştır. Aynı zamanda öğretmen ve veliler de süreç içerisinde çeşitli zorluklarla karşılaşmışlardır. (Özdoğan ve Berkant, 2020). Demir ve Kale'nin (2020) pandemi döneminde gerçekleştirilen uzaktan eğitim süreci hakkında okul öncesi, ilkokul, ortaokul ve özel eğitim kurumlarında görev yapan öğretmenlerin görüşlerine başvurdukları çalışmada, öğretmenlerin çoğu uzaktan eğitim konusunda kendilerini yeterli bilgi ve beceriye sahip olarak görürken, öğretmenlerin bir kısmının başlangıçta kendilerini yeterli görmeyerek zorluk yaşadıkları ve uzaktan eğitim sürecinde kendilerini geliştirdikleri sonucuna ulaşılmıştır. Ayrıca yapılan çalışmada ilkokul ve ortaokul kademelerinde görev yapan öğretmenler, öğrencilerinin internete ulaşmakta ve internet altyapı olmadığı için sıkıntı çektiklerini, derse ilgi ve motivasyonlarının düştügünü, velilerin teknolojik açıdan bilgi eksikliği yaşadığını, müfredatın tam olarak uygulanamadığını, yeterli iletişim ve geri dönütün olmadığı gibi uzaktan eğitimin olumsuz yanları ile karşılaştıklarını belirtmişlerdir. Diğer yandan veli görüşleri üzerine yapılan alan yazına baktığımızda, Günbaş ve Gözüküçük (2020) ilkokul öğrenci velilerine yönelik çalışmalarında çocukların EBA ve canlı derslere girişte zorlandıklarını ve teknik sıkıntılar yaşadıklarını, ayrıca çocukların okuldan uzaklaştıkları ve derslere motive olamadıkları sonucuna ulaşmışlardır. Yılmaz, Güner, Mutlu ve Arın Yılmaz (2020) ise ilkokul ve ortaokulda eğitim gören öğrenci velilerinin pandemi sürecindeki uzaktan eğitim uygulamalarından genel olarak memnun olduğu fakat veli görüşlerine göre uzaktan eğitimin tek başına değil yüz yüze eğitime destek olacak şekilde yapılması gerektiği sonucuna ulaşmışlardır. Ayrıca ilkokul kademesindeki çocukların velilerinin çocuklarının uzaktan eğitime katılırken bağlantı problemi çektiklerini, uzaktan eğitimde internet ve televizyonu birlikte kullandıklarını ve uzaktan eğitim deneyimini yaşadıktan sonra yüz yüze eğitimin önemini daha iyi anladıklarını belirtmişlerdir.

\section{Pandemi Sürecinde Okul Öncesi Eğitimden İlkokula Geçiş}

Okul öncesi dönemden ilkokula geçiş ve 1.sınıfa başlama aşaması öğrenciler ve veliler açısından yenilik ve değişimleri beraberinde getiren bir süreçtir. Okul öncesi eğitim örgün eğitime alışma ve uyum sağlama, öğretmenini tanıma, okul kuralarına uyma hususlarıyla okul hayatına başlama aşamasında en kritik zamanlardır (Çabuk ,2018). Öyle ki okul öncesi eğitim alan çocukların bilişsel, duyuşsal ve psikomotor beceriler yönünden ilkokula hazırbulunuşluklarının okul öncesi eğitim almayanlara nazaran daha yüksek olduğu, bununla birlikte okuma yazma sürecine daha hızlı uyum sağladıkları belirlenmiştir (Bozgün ve Uluçınar Sağır, 2018). Buradan hareketle okul öncesi dönemde alınan eğitim ile öğrencilerin bir nevi ilkokula geçişe hazırlık yaptı̆̆ı, çeşitli deneyim ve yaşantılar sayesinde hazırbulunuşluklarını destekledikleri söylenebilir. Okul öncesi eğitimde kazandırılan akademik, sosyal ve duygusal beceriler çok önemlidir. Ayrıca çocukların hayatlarına bir ömür ışık tutarak ileri düzeydeki eğitim hayatlarını pozitif yönde etkilemektedir (Ekinci Vural ve Kocabaş, 2016; Pişirir, 2020). Ansari ve Pianta' nın (2018) yaptıkları boylamsal çalışmada okul öncesi eğitim sürecinde elde edilen akademik becerilerin ilkokul düzeyinde de devam ettiği ve uzun vadeli olumlu etkileri olduğunu vurgulamışlardır. 
Okul öncesinden ilkokula geçiş aşaması ile ilgili yapılan çalışmalar incelendiğinde, Pişirir (2020) okul öncesinden ilkokula geçişte öğretmenlerin çocukların çeşitli motor kas becerilerinde, sosyal, duygusal ve dil gelişimlerinde ayrıca öz bakım becerileri ve aile tutumundan kaynaklı sorunlarla karşılaştıkları sonucuna ulaşmıştır. Erden ve Altun (2014) okul öncesi eğitime katılan çocuğun okul öncesi eğitime katılmayan çocuğa oranla ilköğretime daha hazır geldiği, sınıfa uyum konusunda daha az sıkıntı yaşadığı, ilköğretime geçişte sosyal becerilerinin daha fazla gelişmiş olduğu sonucuna ulaşmışlardır. Erkan ve Kırca (2010)' ya göre okul öncesi eğitimi alan çocukların ilkokul hazır bulunuşluk düzeyleri, okul öncesi eğitimi almayanlara oranla daha yüksek bulunmuştur. Ayrıca anne babasının eğitimleri yüksek olan çocukların hazır bulunuşluk düzeyleri anne babalarının eğitimleri okur yazar olmayan veya ilkokul mezunu olanlara göre daha yüksek olduğu sonucuna ulaşılmıştır. Kaliteli sunulan okul öncesi eğitim, ilkokula geçiş sürecini kolaylaştırmakta, çocukların gelişim düzeylerini olumlu etkilemekte ve çocukların bu süreçte kazanması gereken becerileri yeterli düzeyde kazanmasını sağlayarak ilerideki eğitim hayatlarını olumlu yönde etkilemektedir. Bakken, Brown ve Downing'in (2017) yaptıkları çalışmada yoksul ailelerin çocuklarına kaliteli okul öncesi eğitim imkânı sunulmuş ve sonrasında çocuklar okul öncesi dönemden ilkokul 4.sınıfa kadar izlenmiştir. Araştırma sonuçları kaliteli bir okul öncesi eğitimin çocuklarda akademik performansta artış sağladığı, sosyal becerileri geliştirdiği ve okula karşı olumlu tutum kazandırdığı belirtilmiştir. Dearing, McCartney ve Taylor (2009) ise yaptıkları boylamsal bir çalışmada yüksek kaliteli okul öncesi eğitim almanın orta çocukluk düzeyinde matematik ve okuma başarısını olumlu etkilediği ayrıca dolaylı olarak kaliteli okul öncesi eğitim almanın okula hazır bulunuşluğu artırdığı sonucuna ulaşılmıştır.

Çocukların okul öncesi eğitimden ilkokula geçişleri yeni bir sınıf ortamı ve okul öncesi eğitimden farklı bir öğretim yöntemiyle karşılaşmaları manasına gelmektedir. Yapılan bir çalışmaya göre çocukların algılarına göre ilkokul ortamı daha akademik ve kurallı olabilmektedir (Einarsdottir, 2003). La Paro ve Pianta (2000) çocukların okul öncesi eğitimden ilkokula geçiş sürecinde sınıf ortamı, öğretmen beklentisi gibi farklılıklarla karşılaştıklarını belirtmişlerdir. Bunun yanı sıra, veliler de okul öncesi eğitimden farklı ve yeni öğretmen, okul kuralları ve prosedürlerle karşılaşmaktadırlar. Dereli (2012) ilkokul dönemini öğretim yöntemi, çevre, aile ve çocukların beklentisi yönleri ile okul öncesinden farklı olduğunu bu nedenle geçiş sürecinin çocuğun hayatında en belirsiz ve karışık dönem olarak ifade etmiştir. İki kademe arasındaki eğitim yaklaşımı, uygulanan program ve çocuktan beklentilerin farklılaşması geçiş sürecini zorlaştırmaktadır. Ancak, geçiş sürecinin başarılı gerçekleşmesinde, okul öncesi eğitim ve ilkokul arasında pedagojik çerçeve (öğrenme ortamı, öğretme stratejileri, eğitimin planlanması ve değerlendirilmesi vb.) açısından devamlılık ön plana çıkmaktadır (UNICEF, 2012). Okul öncesi ve ilkokul kurumları arasındaki iş birliği ve iletişim sorunları, çocukların ilkokula hazır bulunuşluğunda eksiklikler gibi nedenler ise bu süreci olumsuz etkilemektedir (Vecchia, 2011). Başarılı bir geçiş süreci için ise öğrenci-öğretmen, öğretmen-veli, öğrenci-sınıf arkadaşları arasındaki ilişkinin desteklenmesi, öğretmen ve okul yönetiminin velileri sürece dahil etmesi önemli derece etkili olabilmektedir (Brandes, Ormsbee ve Haring, 2007; Yalçın ve Simsar, 2020). Etkili bir iletişim ve iş birliği sayesinde öğrencinin akademik gelişimi, çevreye uyumu, ihtiyaçları gibi konular göz önünde bulundurularak muhtemel problemlerin önüne geçilmektedir. Ancak, olağan dışı pandemi koşullarının sonucunda eğitim sürecindeki farklılıkların okul öncesinden ilkokula geçiş sürecini etkileyebileceği göz önünde bulundurulmalıdır.

Uzaktan eğitim sürecinde okul öncesi ve ilkokul kademelerinde yaşanan çeşitli problemler bazı araştırmalara konu olmuştur. Göktaş, Gülay Ogelman ve Güngör (2020) okul öncesi dönem çocukların sadece $\% 52$ 'sinin çevrimiçi eğitime katıldıklarını ve çevrimiçi eğitimde en sık resim sanat ve oyun etkinliklerinin yapıldığı ortaya konulmuştur. Bu durum çocukların hem okul öncesi eğitime katılımının hem de aldıkları eğitimin içeriğinin pandemi sürecinde olumsuz etkilendiğine işaret etmektedir. Akkaş Baysal, Ocak ve Ocak (2020) ebeveynlerin okul öncesi dönemde çevrimiçi eğitimin kullanılmasının çocukların akademik, duygusal ve sosyal gelişimlerini destekleyecek materyal ve içerik eksikliklerine işaret ettiklerini belirtmişlerdir. Bunlara ek olarak, çocuk ve öğretmen arasındaki etkileşimde yaşanan problemler, pandemide en fazla olumsuzluğun yaşandığı eğitim kademesi olduğu belirtilmiştir (Ozgem, Kan, Kuset ve Şaşmacıoğlu, 2020). Bu problemlerin önüne geçerek uzaktan eğitim ile yapılan okul öncesi eğitimin daha etkili ve verimli olabilmesi için öncelikle ailelerin uzaktan eğitim sürecinde eğitim ihtiyaçlarının giderilmesi ve ailelere rehberlik edilerek süreçle ilgili 
çeşitli bilgilendirmelerin yapılması gerekmektedir. Öğretmenlere ise çocuğun ve ailenin ihtiyaçlarına göre hareket etmeleri ve süreci yönetmeleri önerilmektedir (Aslan ve Akın, 2021; Simsar, 2021).

Gülay Ogelman, Güngör ve Göktaş (2021) Covid-19 sürecinde okul öncesi dönem çocukların okula uyum süreçlerini araştırdıkları çalışmada, öğretmenlerin çocuklarda çeşitli sosyal davranış sorunları, kurallara uymama, öğrenilen bilgilerin unutulması ve aşırı temizlik davranışları ile karşılaştıkları belirtilmiştir. Ayrıca pandemi döneminde öğretmenlerin velilerle olan iletişimin güçlendirilmesi gerektiği araştırmacılar tarafından vurgulanmıştır. Kuzu (2020) ise ilkokul öğrenci velilerinin uzaktan eğitim çalışmalarını yakından takip ettiklerini, pandemi sürecinde çocukları destekleme çabasında olduklarını belirtmiştir.

Erol ve Erol'un (2020) ilkokul öğrencileri üzerine yaptıkları araştırmada velilerin uzaktan eğitime geçiş sürecinin ani olması nedeniyle uyum sağlamanın zorluğu, uzaktan eğitimin yüz yüze eğitim kadar etkin olmaması ve uzaktan eğitimin ilkokul öğrencileri için uygun olmaması hususlarını ön plana çıkardıklarını raporlamışlardır. Araştırmada, öğrencilerin dijital araç kullanımında artış ve akademik başarılarında düşüş olduğu belirlenmiştir. Veliler çocukların eğitiminde daha çok yer aldıkları ve akademik başarıları için destek olmaya çalıştıkları, ancak bazı velilerin süreci yönetmekte yetersiz olduğunu hissettiği ortaya koyulmuştur. Araştırmada öğretmenlerin veli ve çocuklarla olan iletişimi de ayrıca ön plana çıkmıştır. Veliler zaman zaman öğretmenlerin ilgisiz olduğunu belirtmişlerdir. Diğer yandan, veliler öğretmenlerin öğrencilerle doğrudan iletişime geçmesinin çocukları mutlu ve motive ettiğini, öğretmenlerin çocuklarla iletişiminin olumlu yansımaları olduğunu vurgulamışlardır. Bunlara ek olarak, ebeveynlerin çocukların sosyal ilişkilerinin olumsuz etkilendiği ve okula uyum problemi olan öğrencilerin okuldan uzaklaştığ1 görüşünde olduğu araştırmacılar tarafından belirtilmiştir.

Yukarıda çeşitli araştırmacılar tarafından ortaya konulan uzaktan eğitim sürecinde okul öncesi ve ilkokul öğrencilerinin karşılaşabilecekleri problemler, ilkokula geçiş aşamasını etkileyebilecek yapıdadır. Bu nedenle uzaktan eğitim sürecinde karşılaşılan problemlerin ilkokula geçiş bağlamında değerlendirilmesi oldukça önemlidir. Bu araştırma ile uzaktan eğitim sürecine çocukları ile birlikte şahit olan velilerin okul öncesi dönem ile ilkokula geçiş aşamasında yapılan uzaktan eğitim için kullanılan EBA, okul öncesi ve ilkokul düzeyinde kullanılan TRT kanalları (TRT Okul, TRT EBA (Anaokulu, İlkokul) TRT Çocuk) ve Zoom uygulaması hakkındaki görüşlerinin incelenmesi amaçlanmıştır. Bu kapsamda 'Salgında okul öncesi eğitimden ilkokul 1.sınıfa geçen çocukların velilerinin uzaktan eğitim hakkındaki görüşleri nelerdir?' sorusuna cevap aranmıştır. Çalışma, uzaktan eğitim sürecinde okul öncesi eğitimden ilkokula geçişte veli görüşlerinin alınması açısından literatürdeki eksiği gidermesi, uzaktan eğitim faaliyetlerinin okul öncesinden ilkokula geçişte ne derece etkili olduğu, bu süreçte kullanılan uygulamaların eksikliklerini tespit ederek giderilmesinin sağlanması ve bu sayede uzaktan eğitimin kalite ve verimliliğinin artırması açısından önemlidir.

\section{Yöntem}

\section{Araştırma Modeli}

Bu araştırma nitel araştırma türü olan bir durum çalışması olarak tasarlanmıştır. Yıldırım ve Şimşek'e (2018) göre durum çalışmaları bilimsel sorularla belirli bir durum veya sistemin derinlemesine irdelendiği ve sonuçların detaylandırıldığı bir yöntemdir. Araştırma kapsamında çocukların salgın döneminde uzaktan eğitim ile okul öncesi eğitimi tamamlayıp ilkokula geçmesine ait veli görüşleri incelenmiştir.

\section{Katılımcilar}

Araştırmanın çalışma grubu 20 veliden oluşmaktadır. Katılımcı seçiminde kriter, çocukları pandemi döneminde uzaktan eğitim ile hem okul öncesi eğitime katılmış hem de devamında 2020-2021 eğitim öğretim yılında 1.sınıf eğitimine halihazırda devam eden öğrenci velileri olmuştur. Gönüllülük ön planda tutularak kar topu örnekleme yoluyla katılımcılara ulaşılmış ve 2020-2021 eğitim öğretim yılının güz döneminde veriler toplanmıştır. Katılımcı gizliliğini sağlamak amacıyla çalışmaya katılan velilerin isimlerine yer verilmeyerek V1, V2...V20 şeklinde kısaltmalar kullanılmıştır. 
Tablo 1. Katılımcı Velilere Ait Demografik Özellikler

\begin{tabular}{|c|c|c|c|}
\hline Değişkenler & & $\mathrm{n}$ & $\%$ \\
\hline \multirow[t]{3}{*}{ Yaş } & $20-29$ yaş & 4 & 20 \\
\hline & 30-39 yaş & 15 & 75 \\
\hline & $40-49$ yaş & 1 & 5 \\
\hline \multirow{2}{*}{ Cinsiyet } & Kadın & 19 & 95 \\
\hline & Erkek & 1 & 5 \\
\hline \multirow{4}{*}{ Eğitim durumu } & İlkokul & 5 & 25 \\
\hline & Ortaokul & 1 & 5 \\
\hline & Lise & 8 & 40 \\
\hline & Üniversite & 6 & 30 \\
\hline \multirow{4}{*}{ Meslek } & Ev hanımı & 15 & 75 \\
\hline & Hemşire & 1 & 5 \\
\hline & Öğretmen & 3 & 15 \\
\hline & Memur & 1 & 5 \\
\hline \multirow{2}{*}{ Çalışma Durumu } & Çalışıyor & 4 & 20 \\
\hline & Çalışmıyor & 16 & 80 \\
\hline \multirow{3}{*}{ Gelir durumu } & Asgari ücret & 7 & 35 \\
\hline & 3-5 Bin TL & 8 & 40 \\
\hline & 7 Bin TL ve üzeri & 5 & 25 \\
\hline \multirow{4}{*}{ Çocuk sayısı } & 1 & 1 & 5 \\
\hline & 2 & 12 & 60 \\
\hline & 3 & 6 & 30 \\
\hline & 4 & 1 & 5 \\
\hline
\end{tabular}

Çalışmaya katılan velilerin çoğunu kadın (\%95) veliler, geriye kalan \%5'i ise erkek veliler oluşturmaktadır. Velilerin büyük çoğunluğunun yaşı 30-39 yaş (\%75) aralığında olup, \%20'si 20-29 yaş ve \%5'i ise 40-49 yaş aralığındadır. Velilerin \%30'u üniversite, \%40'1 lise, \%5' i ortaokul ve \%25'i ilkokul mezunudur. Meslek durumlarına bakıldığında büyük çoğunluğunun ev hanımı (\%75) olduğu, \%15'inin öğretmen, \%5'inin hemşire ve geriye kalan \%5'inin ise memur olduğu görülmektedir. Velilerin \%20'sini aktif olarak çalışan veliler, $\% 80$ 'ini ise çalışmayan veliler oluşturmaktadır. Gelir durumuna bakıldığında velilerin \%35'inin asgari ücret aldığı, \%40'ının 3-5 Bin TL arasında ve \%25'inin ise 7 Bin TL üzerinde geliri olduğu görülmektedir. Velilerin \%5'inin 1 çocuğu, \%60'ının 2 çocuğu, \%30'unun 3 çocuğu ve geriye kalan \%5'inin ise 4 çocuğu olduğu belirtilmiştir.

Tablo 2. Katılımcıların Okul Öncesi Ĕ̆itimine Katılan Çocuklarına Ait Bilgiler

\begin{tabular}{llll}
\hline Değişkenler & & $\mathrm{n}$ & $\%$ \\
\hline Okul Öncesi Eğitime Katılan & 2013 & 2 & 10 \\
Çocuğun Doğum Tarihi & 2014 & 18 & 90 \\
\hline Okul Öncesi Eğitime Katılan & Kız & 9 & 45 \\
Çocuğun Cinsiyeti & Erkek & 11 & 55 \\
\hline & 1 Yıl & 14 & 70 \\
Çocuğun Toplam Okul Öncesi & 2 yıl & 3 & 15 \\
Eğitim Alma Süresi & 3 yıl & 1 & 5 \\
& 4 yıl & 2 & 10 \\
\hline
\end{tabular}

Çalışmaya katılan velilerin okul öncesi eğitime katılan çocuklarının; \%90'ı 2014 doğumlu geriye kalan \%10'u ise 2013 doğumludur. \%55'i erkek çocuğu, \%45'i ise kız çocuğudur. Çocuklardan \%70'inin sadece 1 yıl okul öncesi eğitime katıldığı, \%15'inin 2 yıl, \%5'inin 3 yıl ve geriye kalan \%10'unun ise 4 yıl okul öncesi eğitime katıldığı tespit edilmiştir.

\section{Verilerin Toplanması}

Araştırmada veri toplamak için yarı yapılandırılmış görüşme formu kullanılmıştır. Görüşmenin başlangıcında velilerin demografik özellikleri sorulmuştur. Daha sonra açık uçlu sorulardan oluşan yarı yapılandırılmış görüşme formu aracılığıyla veri toplanmıştır. Görüşme formunda bulunan sorular konu ile ilgili literatür incelemesi sonucunda taslak olarak hazırlanmış sonrasında pilot uygulama yapılarak amaca hizmet etmeyen, anlaşılması zor olan sorular değiştirilmiştir. Pandemi sürecinde uzaktan eğitim ile okul 
öncesinden ilkokula geçişte veli görüşlerinin öğrenilmesi için hazırlanan görüşme formunda aşağıdaki sorulara cevap aranmıştır:

1. Geçen yıl pandemi dönemi başlangıcından itibaren çocuğunuz okul öncesi eğitime nasıl katıldı?

2. Geçen yıl pandemi dönemi başlangıcından itibaren çocuğunuz evde okul öncesi eğitim sürecini nasıl geçirdi?

3. Geçen yıl pandemi başlangıcından yıl sonuna kadar yapılan okul öncesi eğitim sürecinin olumlu ve olumsuz yönleri nelerdir?

4. Çocukların okul öncesi eğitimi tamamlayarak ilkokul 1. sınıfa başlama sürecinde uzaktan eğitimin daha etkili ve faydalı olabilmesi için görüş ve önerileriniz nelerdir?

5. Sizce ilkokul başlangıcında çocuğunuzun uzaktan eğitim sürecinde kullandığı uygulamaların (TRT, ZOOM, EBA) olumlu ve olumsuz özellikleri nelerdir?

6. İlkokul başlangıcında çocuğunuzun uzaktan eğitim sürecinde kullandığı uygulamaların (TRT, ZOOM, EBA) daha etkili ve faydalı olabilmesi için görüş ve önerileriniz nelerdir?

Veri toplama sürecine geçilmeden önce Erciyes Üniversitesi Sosyal ve Beşeri Bilimler Etik Kurulu'ndan onay alınmıştır (2021/62). Verilerin toplanma süreci gönüllü veliler ile 15-25 dakikalık telefon görüşmeleri şeklinde ikinci araştırmacı tarafından gerçekleştirilmiştir. Araştırma başlangıcında katılımcı velilere çalışmanın amacı hakkında bilgi verilmiş ve gönüllü katılımlarını beyanları sonrasında görüşme sorularına geçilmiştir. Katılımcıların onayı neticesinde veri kaybı olmaması amacıyla görüşmeler ses kaydı altına alınmıştır.

\section{Verilerin Analizi}

Araştırma sonucunda elde edilen veriler içerik analizi yöntemi ile analiz edilerek çözümlenmiştir. İçerik analizinde, belirli kurallara bağlı olarak birbirine benzer verileri küçük içerik kategorilerine ayırarak kavramsallaştırılır ve daha sonra elde edilen kavramlar düzenlenerek veriyi açılayan temalar elde edilir (Büyüköztürk, Kılıç Çakmak, Akgün, Karadeniz ve Demirel, 2018). Asıl yapılan işlem verileri birbirine benzeyen kavram ve temalar kapsamında bir araya toplayarak özetlemek ve okuyucu tarafından daha kolay anlaşılması ve yorumlanmasını sağlamaktır.

Verilerin analizi sürecinde $\mathrm{O}^{\prime}$ Connor ve Joffe'nin (2020) önerdiği üzere iki kodlayıcı yer almıştır. Öncelikle, çalışmada elde edilen veli görüşme ses kayıtları yazıya dönüştürülerek ön okumalar yapılmıştır. Sonrasında her iki araştırmacı toplanan verilerin yaklaşık \%20'sini ayrı ayrı kodlamışlar ve bir araya gelerek oluşan kodları karşılaştırmışlardır. Böylece kodların son haline karar verilerek verilerin tamamının kodlaması gerçekleştirilmiştir. Kodlama sürecinde Lincoln ve Guba'nın (1985) kodlama prosedürü çerçevesinde ortaya çıan yeni kodlar göz önünde bulundurulmuş ve bazı kodlar birleştirilmiştir. Oluşturulan kodlar verilerde bulunan kavramları belirlemeye yönelik yapılmış ve devamında benzer kodlar bir araya getirilerek temalar elde edilmiştir. Son olarak, kategorilerdeki birimler sayılarak frekanslar elde edilmiş ve bulgulardan yola çıkılarak sonuçlara ulaşılmıştır.

\section{Bulgular}

Çalışmanın bu bölümünde pandemi sürecinde uzaktan eğitim ile okul öncesi eğitimden ilkokula geçiş hakkında velilerin görüşlerine yer verilmiştir. Ayrıca uzaktan eğitim sırasında velilerin hangi araçları ve uygulamaları kullandıkları, internet bağlantısı türleri, çocuklarının günde ne kadar uzaktan eğitime zaman ayırdığı ve uzaktan eğitime katılan çocuk sayıları ve seviyeleri hakkında bilgiler bulunmaktadır. 

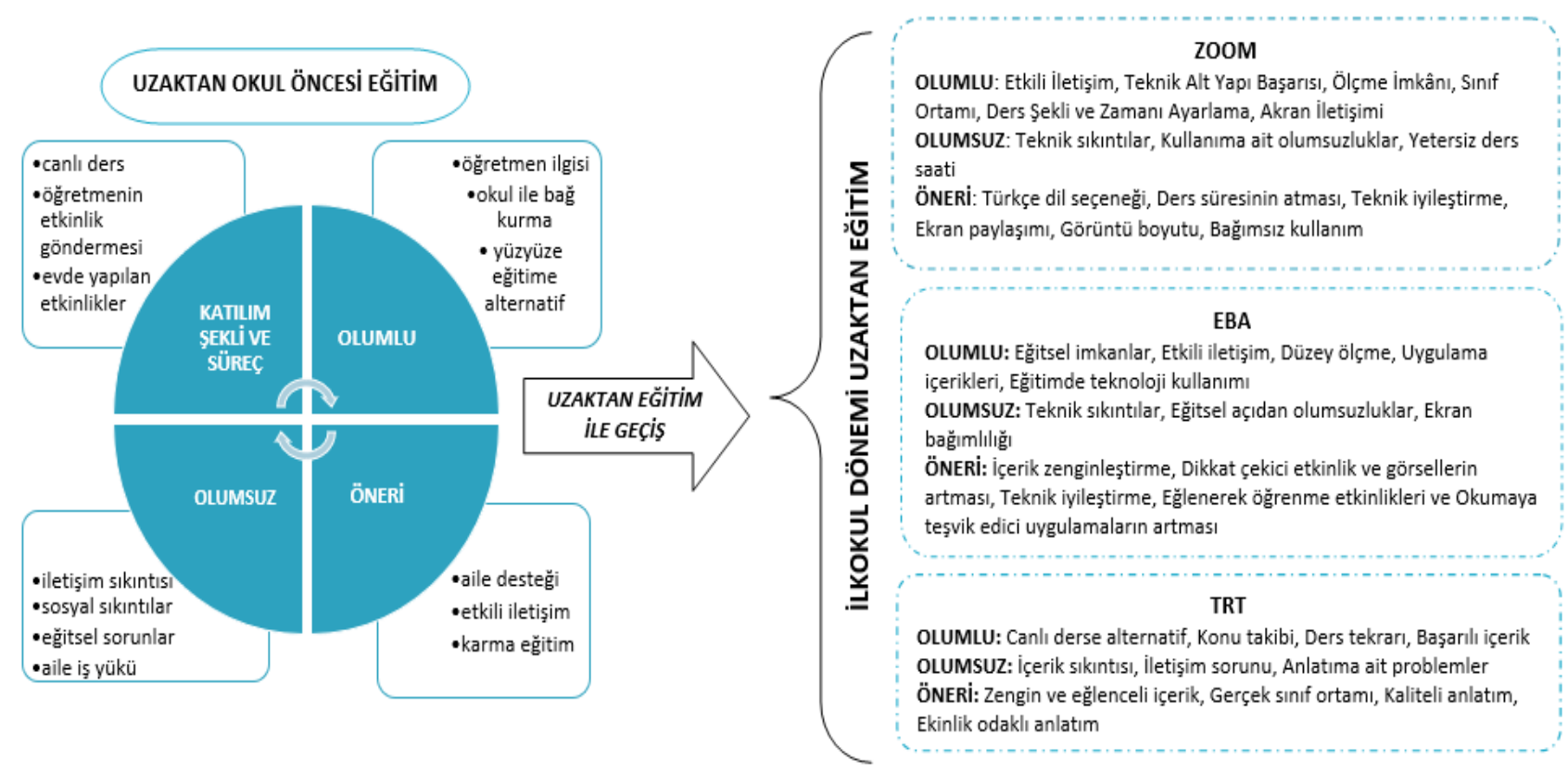

Şekil 1.Uzaktan eğitim ile yapılan okul öncesinden ilkokula geçiş süreci hakkında veli görüşlerine ait bulgular

Yukarıda yer alan Şekil 1'de araştırmadan elde edilen bulguların özetini içeren görsel bulunmaktadır. Bu görsele göre uzaktan okul öncesi eğitime yönelik katılım şekli ve süreç, olumlu ve olumsuz yönler ile öneriler yer almaktadır. Diğer yandan ilkokul döneminde uzaktan eğitimde Zoom, EBA ve TRT başlıkları altında olumlu ve olumsuz yönler ile öneriler bulunmaktadır.

Tablo 3. Velilerin Uzaktan Ĕ̆itime Katılım Bilgileri

\begin{tabular}{lll}
\hline Değişkenler & & $n$ \\
\hline Uzaktan Eğitime & 1 çocuk & 10 \\
Katılan Çocuk Sayısı & 2 çocuk & 8 \\
& 3 çocuk & 2 \\
\hline Uzaktan Eğitime & ̇lkokul & 26 \\
Katılan Çocuklarının & Ortaokul & 4 \\
Sinıf Seviyesi & Lise & 2 \\
\hline \multirow{2}{*}{ Uzaktan Eğitimde } & Ev Sinırsız İnternet & 16 \\
Kullanılan İnternet Türü & Telefon internet paketi & 3 \\
\hline & Ev Kotalı İnternet & 2 \\
Uzaktan Eğitimde & Akıllı telefon & 14 \\
Kullanılan Araçlar & Bilgisayar & 8 \\
& TV & 6 \\
\hline Uzaktan Eğitim İçin & Tablet & 5 \\
1 Günde Harcanan Zaman & $3-5$ Saat & 15 \\
\hline TRT (okul-eba) & 5 saat ve üzeri & 5 \\
Kullanma Durumu & Evet & 6 \\
\hline Eba Kullanma Durumu & Hayır & 14 \\
\hline Zoom Kullanma Durumu & Evet & 18 \\
& Hayır & 2 \\
\hline
\end{tabular}

Tablo 3'ten yola çıkarak uzaktan eğitime katılan çocuk sayılarına bakıldığında 10 velinin sadece bir çocuğu, 8 velinin iki çocuğu ve 2 velinin de üç çocuğunun birden uzaktan eğitime katıldıkları tespit edilmiştir. Veliler çocukların aynı anda uzaktan eğitime katılması sırasında sıkıntı yaşadıklarını ve uzaktan eğitim için kullandıkları teknolojik araçların sayıca yetersiz geldiğini belirtmişlerdir. Çalışmaya katılan 20 veliden sadece 
6'sının TRT Okul-EBA kullandığı,18'inin EBA kullandığı ve bütün velilerin Zoom uygulaması kullandığ1 tespit edilmiştir. Bu bilgilerden yola çlkılarak velilerin EBA ve Zoom uygulamalarına daha çok önem vererek kullandıklarını söyleyebiliriz. TRT kanalları üzerinden yapılan uzaktan eğitimi çoğu velinin kullanmağı görülmektedir. Uzaktan eğitime katılmak için çoğu velinin ev sınırsız internet kullandığı (16 veli), 3 velinin telefon internet paketi ve 2 velinin de ev kotalı internet kullandıkları görülmüştür. Bazı veliler uzaktan eğitime daha rahat katılabilmek için sınırsız internet bağlantısını kullandıklarını belirtmişlerdir. Uzaktan eğitime katılırken en çok akıllı telefon (14) kullandığı görülmektedir ve bunun yanında TV, bilgisayar ve tablet kullandıklarını söyleyen velilerde bulunmaktadır. 15 veli çocukların bir günde uzaktan eğitime 3-5 saat zaman harcadıklarını, 5 veli ise 5 saatten fazla zaman harcadıklarını belirtmiştir. Çocukların bu zaman dilimlerini canlı dersler ve ödevlerle geçirdikleri belirtilmiştir.

Tablo 4. Pandemi Döneminde Çocukların Okul Öncesi Eğitime Nasıl Katıldıkları ve Bu Süreci Evde Nasıl Geçirdikleri ile İlgili Veli Görüşleri

\begin{tabular}{lll}
\hline Tema & Alt Tema & Kodlar \\
\hline \multirow{3}{*}{ Okul öncesi eğitime katılım şekli } & Hiç katılmadı & Öğretmen tarafından ders ve etkinlik olmadı \\
& Öğretmenin gönderdiği etkinlikler & Telefon-Whats App etkinlik \\
& Canlı ders & EBA \\
& & Zoom \\
& Etkinlik olmadı & Öğretmen tarafından tavsiye kitap \\
\hline & Evde yapılan etkinlikler & Veli tarafından evde ekstra hiçbir şey yapılmadı \\
& & Öğretmen tavsiyesi etkinlik \\
& & Velinin kendi oluşturduğu etkinlik \\
& & Harf ve sayı etkinlikleri \\
Evde aile ile yapılan uygulamalar oluşturduğu etkinlikler & Çizgi, resim, boyama ve kalem tutma etkinlikleri (el- \\
& & göz koordinasyonu) \\
& & İnce motor kas beceri etkinlikleri \\
& & Eğitici oyunlar \\
& Tekrar etkinlikleri \\
& Sanal etkinlikler & Çevreden öğrenilen etkinlikler \\
& Aile desteği & TV, tablet ve medya \\
& & Anne \\
& Kardeş \\
\hline
\end{tabular}

Tablo 4 incelendiğinde 7 veli uzaktan eğitim sürecinde çocuklarının hiç uzaktan eğitime katılamadıklarını, uzaktan eğitime katılan diğer velilerin görüşlerine bakıldığında ise bazısı öğretmenin EBA ve telefon-Whats App uygulaması üzerinden etkinler gönderdiğini, bazısı Zoom üzerinden canlı ders yapıldığını ve öğretmenin tavsiye ettiği kitap üzerinden ders işlendiğini söyleyerek uzaktan eğitime katıldıklarını belirtmişlerdir. Velilerin uzaktan eğitim sürecini evde nasıl geçirdikleri ile ilgili görüşlerine bakıldığında 4 veli bu süreçte evde ek olarak hiçbir çalışma yapmadığını belirtmiştir. Geri kalan veliler ise öğretmenin tavsiye ettiği etkinlikleri yaptıklarını ya da evde kendileri tarafından oluşturulan en çok harf ve sayı etkinlikleri yaptıklarını ayrıca çizgi, resim, boyama ve kalem tutma gibi el-göz koordinasyonu geliştirici çalışmaları kullanarak ince motor kas becerilerini destekleyici etkinliklerden yararlandıklarını bunun yanında eğitici oyunlar ve tekrar etkinliklerini yaptıklarını aynı zamanda komşu veya akrabaları aracılı̆̆ ile çevrelerinden de çeşitli etkinlik tavsiyeleri alarak evde çocuklarına uyguladıklarını belirtmişlerdir. Bazı veliler bu süreçte televizyon, tablet ve medya araçları üzerinden çeşitli videolar, şarkılar ve oyunlardan faydalandıklarını belirtmişlerdir. Ayrıca evde aile ile yapılan etkinliklerde çocukların en büyük destekçilerinin anneleri olduğu ve bu süreçte babaların geri planda kaldığı fakat yaşça büyük kardeşi olan birkaç çocuğa kardeşlerinin de yardımcı olduğu belirtilmiştir. Çocuklarının okul öncesi eğitime nasıl katıldıkları ve bu süreci evde nasıl geçirdikleri ile ilgili örnek veli görüşü aşağıda yer almaktadır.

\footnotetext{
‘Öğretmen telefon üzerinden etkinlikler gönderdi fakat bu etkinliklerin yetersiz kaldığını düşündüğüm için evde kendim araştırarak çeşitli etkinlikler hazırladım. Kalem tutma ve boyama çalışmaları, harf etkinlikleri bunun yanında çeşitli videolar ve şarkılardan yararlanarak farklı etkinlikler yaptık.' (V6)

'Öğretmenimiz internet üzerinden etkinlikler gönderdi ve biz de bu etkinlikleri yaparak öğretmene gönderiyorduk. Öğretmen ile sürekli iletişim halindeydik. Öğretmenin gönderdiği etkinlikler yeterli olduğu için bunun dışında evde ekstra bir şey yapmadık.' (V10)
} 
Pandemi Sürecinde Uzaktan Eğitim ile Okul Öncesi...

Tablo 5. Geçen Yal Pandemi Başlangııından Yıl Sonuna Kadar Yapılan Okul Öncesi Ĕ̆itim Sürecinin Olumlu ve Olumsuz Yönleri Nelerdir? Sorusuna Ait Bulgular

\begin{tabular}{|c|c|c|}
\hline Tema & Alt tema & Kodlar \\
\hline \multirow{6}{*}{ Olumlu yön } & \multirow{6}{*}{ Yüz yüze eğitim } & Yok-hiç \\
\hline & & Öğretmen ilgisi \\
\hline & & Okul ile bağ kurma \\
\hline & & Yeterli dönüt ve düzeltme \\
\hline & & Yüzyüze eğitime alternatif \\
\hline & & Yüzyüze eğitim kadar iyi eğitim \\
\hline \multirow{9}{*}{ Olumsuz yön } & \multirow{3}{*}{ Eğitsel açıdan olumsuzluklar } & Yok-hiç \\
\hline & & $\begin{array}{l}\text { Bilgileri unutma (Tekrar eksikliği) } \\
\text { Canlı ders olmaması }\end{array}$ \\
\hline & & Yeterli bilgi ve beceri kazanılmaması \\
\hline & \multirow{3}{*}{ İletişim sıkıntısı } & Öğretmenle iletişim yetersizliği \\
\hline & & Dönüt-düzeltme eksikliği \\
\hline & & Yeterli ödevlendirme olmaması \\
\hline & Sosyal açıdan olumsuzluklar & $\begin{array}{l}\text { Okuldan soğuma-uzaklaşma } \\
\text { Öğretmen ve arkadaş özlemi } \\
\text { Yeterli sosyalleşememe } \\
\text { Özgüven kazanamama }\end{array}$ \\
\hline & Aile iş yükü & Aileye düşen görevler \\
\hline & Ekran bağımlılı̆̆ğ & Teknoloji bağımlılığı \\
\hline
\end{tabular}

Tablo 5 incelendiğinde uzaktan eğitimle yapılan okul öncesi eğitim sürecinin olumlu yönlerine ait veli görüşlerine bakıldığında velilerin yarısından fazlası (12 veli) hiçbir olumlu yönü olmadığını ve memnun olmadıklarını belirtmişlerdir. Bunun nedeni olarak ise bu süreçte çoğu öğrencinin okul öncesi eğitime uzaktan hiç katılamadığı gösterilebilir ayrıca uzaktan eğitime katılabilmesine rağmen yaşadıkları olumsuzluklar sonucunda memnun olmayan velilerde bulunmaktadır. Veliler pandemi sürecinde uzaktan eğitimle verilen okul öncesi eğitimin yüz yüze eğitime tek alternatif yol olduğunu düşünmektedir hatta bir veli uzaktan eğitimle verilen eğitimin yüz yüze eğitim kadar iyi olduğunu belirtmiştir. Bunun yanında veliler bu süreçte öğretmenin uzaktan eğitim sayesinde çocuklarla ilgilenerek yeterli dönüt ve düzeltme verebilme imkânı bulduğunu ayrıca çocukların okul öncesinde verilen uzaktan eğitim ile okulla bağ kurabildiklerini ve bu sayede okuldan soğumadıklarını düşünmektedirler. Uzaktan eğitim ile yapılan okul öncesi eğitimin olumlu yönleri ile ilgili örnek veli görüşlerine aşağıda yer verilmiştir.

\footnotetext{
‘Hiç ders işlememektense uzaktan eğitim yapmanın faydalı olduğunu düşünüyorum. Öğretmenin gönderdiği etkinlikleri yaparak ve öğretmenle sık sık iletişim sağlayarak yeterli dönüt ve düzeltme aldık bu sayede çocuğum okul ile bağını koparmadı.'(V9)

'Yüz yüze eğitim aldığımız eğitim kadar iyi eğitim aldık. Uzaktan eğitim döneminde öğretmenimiz çok ilgiliydi.'(V16)
}

Pandemi döneminde uzaktan eğitimle yapılan okul öncesi eğitim sürecinin olumsuz yönlerine ait veli görüşlerine bakıldığında eğitsel ve sosyal açıdan olumsuzluklar, iletişim sıkıntısı, aile iş yükü ve ekran bağımlılığı şeklinde 4 alt tema altında bulgular kategorize edilmiştir. Bunun yanında bu süreçte yapılan uzaktan eğitimin hiç olumsuz yanı olmadığını düşünen veliler de mevcuttur. Eğitsel açıdan yaşanan olumsuzluklara bakıldığında canlı ders olmaması veliler tarafından en büyük olumsuzluk olarak belirtilmiştir. Bununla beraber tekrar eksikliği ve yeterli bilgi beceri kazanılamaması da eğitsel olumsuzluklar arasında bulunmaktadır. Bu süreçte iletişim ile ilgili yaşanan olumsuzlukların başında ise öğretmenle iletişim kuramama gelmektedir. Bu kapsamda öğretmenin yeterli ödev göndermemesi ve yeterli dönüt düzeltme olmaması da iletişim sıkıntısı olarak veliler tarafından belirtilmiştir. Veli görüşlerine göre sosyal açıdan yaşanan olumsuzluklara baktığımızda ilk sırada çocukların okuldan soğuma ve uzaklaşması gelmektedir. Bazı veliler çocuklarının öğretmen ve arkadaş özlemi çektiğini, yeterli sosyalleşemediğini ve özgüven kazanamadığını belirtmişlerdir. Uzaktan eğitim sürecinde bazı veliler kendilerine düşen iş yükünün çok arttığını bu nedenle zorlandıklarını ifade ederken bir başka veli uzaktan eğitim yüzünden çocuğunun teknoloji ve ekran bağımlısı olduğunu ifade etmiştir. Uzaktan eğitim ile yapılan okul öncesi eğitimin olumsuz yönleri ile ilgili örnek veli görüşlerine aşağıda yer verilmiştir. 
'Bu süreçte canlı ders olamadı. Çocuğum bu dönemde öğrenmesi gereken ritmik sayma, rakam ve sayılar gibi bilgi ve becerileri öğrenemedi ayrıca boyama, kes yapıştır gibi etkinliklerde eksik kaldı. Bu süreçte öğretmenle iletişim sıkıntısı yaşadık bu nedenle eksik kalan alanları çocuğuma kazandırabilmek için ben çok uğraştım, bütün yük annesi olarak benim üzerime kaldı ve çok sıkıntı çektim bu konuda.'(V6)

'Bu sürecin olumlu geçtiğini söyleyemem. Çocuğuma okul sevgisi kazandırmada yetersiz kaldı ayrıca çocuğumun sosyalleşme ve öz güven kazanma becerileri gelişemedi.'(V13)

Tablo 6. Okul Öncesinden Illkokula Geçiş Sürecinde Uzaktan Eğitimin Daha Etkili ve Faydalı Olabilmesi İçin Görüss ve Önerileriniz Nelerdir? Sorusuna Ait Bulgular

\begin{tabular}{lll}
\hline Tema & Alt tema & Kodlar \\
\hline & Yok-hiç & Gayet memnunum \\
Etkili ders yapma & Canlı ders \\
& Kaliteli ders işleme \\
Aile desteği & Ailelere destek sağlama \\
Karma(hibrit) eğitim & Yüz yüze eğitim ile uzaktan eğitim beraber yürümeli \\
& Etkili iletişim & Öğretmenle etkili iletişim \\
& Öğretmenin etkinlik göndermesi \\
& Öğretmenin daha ilgili olması \\
& Yeterli dönüt düzeltme (ödev kontrolü, ödül-pekiştireç) \\
\hline
\end{tabular}

Tablo 6 incelendiğinde okul öncesinden ilkokula geçiş sürecinde uzaktan eğitimin daha etkili ve faydalı olabilmesi için veli görüş ve önerilerine ait bulgulara baktığımızda etkili ders yapma, aile desteği, karma (hibrit) eğitim ve etkili iletişim şeklinde 4 alt tema kapsamında kategorize edilmiştir. Bunların yanında hiçbir öneri belirtmeyen ve su anki haliyle memnun olduğunu ifade eden veliler de mevcuttur. Etkili ders yapma önerisi kapsamında veliler tarafından en çok ifade edilen öneri canlı ders yapılmasıdır. Bunun yanında uzaktan eğitim sürecinde daha kaliteli ders işlenmesi gerektiğini belirten veliler bulunmaktadır. Veliler tarafından en sıklıkla önerildiği gibi bu süreçte canlı derslerin yapılması aynı zamanda derslerin kalitesinin de artmasına neden olabilir. En sıklıkla önerilen ikinci şey ise öğretmenle etkili iletişimin artması olmuştur. Bunun yanında öğretmenin daha ilgili olması, etkinlik göndermesi ve yeterli dönüt düzeltme (ödev kontrolü, ödül-pekiştireç) sağlaması gerektiği önerilmektedir. Katılımcı 4 veli tamamen uzaktan eğitim olması yerine yüz yüze eğitim ile uzaktan eğitimin beraber karma eğitim şeklinde yürütülmesi gerektiğini önermişlerdir. Ayrıca bu süreçte ailelere düşen görevlerin artması nedeniyle aile desteği sağlanması gerektiği önerilmektedir. İlkokula geçiş sürecinde uzaktan eğitimin daha etkili ve faydalı olabilmesi ile ilgili örnek veli görüşleri aşağıda yer almaktadır.

\footnotetext{
‘Bu dönemde öğretmenin bizimle daha çok ilgilenmesini ve sayıları, rakamları ve renkleri öğretmek için daha çok etkinlik göndermesini isterdim. Ayrıca evde yaptığımız etkinlikleri öğretmene göndererek dönüt düzeltme alabilmek çok faydalı olurdu. Bu süreçte velilere destek olunması gerektiğini düşünüyorum. Çünkü veliler olarak bazen bizlerde ne yapacağımızı bilmiyoruz ve verimli olamıyoruz. Hem öğretmen açısından hem de ev ortamında desteğe ihtiyaç duyuyoruz.'(V11)

'Öğretmenin canlı dersler yaparak ders işlemesini ve çocuğumun öğretmeni ile yüz yüze görüşebilmesini isterdim. Tamamen uzaktan eğitim yerine kısıtlamalı da olsa haftada 2 gün yüzyüze eğitim ile uzaktan eğitim birlikte yürütülebilirdi.'(V17)
}

Tablo 7. Ilkokul Başlangıcında Uzaktan Ĕ̆itim Sürecinde Kullamlan Trt Okul-Eba Uygulamasının Olumlu ve Olumsuz Özellikleri Nelerdir? Sorusuna Ait Bulgular

\begin{tabular}{lll}
\hline Tema & Alt tema & Kodlar \\
\hline & & Hiç yok \\
& Konu takibi \\
Olumlu yön & Ders tekrarı \\
& Başarılı eğitsel içerik \\
& Canlı derse alternatif \\
\hline \multirow{2}{*}{ Olumsuz yön } & Zekâ gelişimine etki \\
\hline
\end{tabular}




$\begin{array}{ll} & \text { Anlaşılması zor } \\ \text { İletişim sıkıntısı } & \text { Öğretmenle iletişimsizlik } \\ & \text { Dönüt düzeltme eksikliği } \\ & \\ \text { Anlatıma ait olumsuzluklar } & \text { Dikkat çekmede yetersiz } \\ & \text { Sıkıcı } \\ & \text { Çok hızlı anlatım } \\ & \text { Odaklanma problemi } \\ & \text { Tek düze anlatım }\end{array}$

Veliler tarafından TRT Okul-EBA uygulamasının çok tercih edilmediğinden daha önce bahsedilmişti. Bununla birlikte bu uygulamayı kullanan velilerin Tablo 7'de bulunan uygulamanın olumlu yönü ile ilgili düşünce ve görüşlerine bakıldığında canlı derse alternatif olarak görüldügü̈, konu takibi ve ders tekrarı sağladığı, eğitsel içeriğin başarılı olduğu ve zekâ gelişimine etki ettiği seklinde görüşlere yer almaktadır. Bunun yanında uygulamanın hiçbir olumlu yönü olmadığını düşünen velilerde (2 veli) bulunmaktadır. TRT Okul-EBA uygulamasının olumsuz yönlerine bakıldığında içerik sıkıntısı, iletişim sıkıntısı ve anlatıma ait olumsuzluklar şeklinde 3 alt tema altında kategorize edilmiştir. Ayrıca hiç olumsuz yönü olmadığını söyleyen veli görüşleri de bulunmaktadır. En sıklıklar dile getirilen olumsuzluk ders anlatımı kısmının dikkat çekmede yetersiz olduğu yönüdür. Devamında anlatımın sıkıcı olduğu, çok hızlı ve tek düze bir anlatım olduğu bu nedenle çocukların derse odaklanma problemi yaşadığı belirtilmiştir. TRT kanalları üzerindeki uygulamalarda öğrenci ile öğretmen arasında iletişim problemi olduğu ve bu kapsamda dönüt düzeltme eksikliği yaşandığı belirtilmiştir. Ayrıca anlatılan derslerin içerik olarak yetersiz kalması ve zor anlaşılması uygulamanın olumsuz görülen yanlarıdır. İçerik kaynaklı olumsuzlukların aynı zamanda ders anlatımına ait olumsuzlukları beslediği yorumu yapabiliriz. TRT Okul-EBA uygulamasının olumlu ve olumsuz yönlerine ait örnek veli görüşü aşağıda yer almaktadır.

\footnotetext{
'Trt okul-eba uygulamasının faydalı olduğunu düşünüyorum. Çünkü çocuğum dersleri buradan takip ederek canlı derslerde işlenen konuları tekrar etmiş oluyor ayrıca canlı derslere katılamasa bile dersleri buradan izleyerek konuya aşina oluyor ve konulardan geri kalmıyor. Bu yönüyle canlı derslere alternatif oluyor. Bununla birlikte bu uygulamanın olumsuz yönlerinin olduğunu da düşünüyorum. Çocuğum bazen dersleri anlamada zorlanıor. Dersler sırasında çocuklar öğretmenle iletişime geçemedikleri için dikkatleri dağllıyor.'(V9)

‘Bu uygulama için olumlu bir yön bulamadım çünkü küçük çocuklar için sıkıcı geliyor. Sabit ve tek renk tahta önünde bir öğretmen yazıyor, çiziyor sürekli. Bu nedenle çocuğum odaklanma problemi yaşıor ve dikkatini uzun süre tutamiyor.'(V3)
}

Tablo 8. Illkokul Başlangıcında Uzaktan Eğitim Sürecinde Kullanılan TRT Okul-EBA Uygulamasının Daha Etkili ve Faydalı Olabilmesi İçin Görüş ve Önerileriniz Nelerdir? Sorusuna Ait Bulgular

\begin{tabular}{ll}
\hline Tema & Kodlar \\
\hline & Yok-hiç \\
& Eğlenceli ve dikkat çekici içerik \\
& Kaliteli anlatım \\
Öneriler & Daha etkinlik odaklı \\
& Uzun süreli konu anlatımı \\
& Eğitsel içerik zenginleştirme \\
& Gerçek sinıf ortamı \\
\hline
\end{tabular}

Tablo $8^{\prime}$ de yer alan bulgulara göre veliler en çok TRT Okul-EBA uygulamasında eğlenceli ve dikkat çekici içeriklerin artmasını istiyorlar. Ayrıca uygulamanın eğitsel içerik yönünden zenginleştirilmesi gerektiğini düşünüyorlar. Devamında derslerin daha çok etkinlik odaklı olmasını, daha kaliteli anlatım olması gerektiğini ifade etmişlerdir. Konuların hızlıca anlatılıp geçilmesinden ziyade konular üzerinde daha uzun durulmasını ve öğrencilere gerçek sınıf ortamı sağlanmasını gerektiği önerilmiştir. TRT Okul-EBA uygulamasının daha etkili ve faydalı olabilmesi ile ilgili örnek veli görüşleri aşağıda yer almaktadır.

'Daha kaliteli ders anlatım olması gerektiğini düşünüyorum. Konular çok hızlı geçilmemeli ve konular üzerinde daha fazla durulmalı. Daha fazla etkinliklere yer verilmeli.'(V6)

'Iç̧eriklerin eğitsel yönden zenginleştirilmesi gerekli. Daha etkinlik odaklı konular dahil edilebilir. Zekâ gelişimini destekleyecek eğlenceli hikaye ve çizgi filmler eklenebilir.'(V4) 
Tablo 9. İlkokul Başlangıcında Uzaktan Eğitim Sürecinde Kullanılan Eba Uygulamasının Olumlu ve Olumsuz Özellikleri Nelerdir? Sorusuna Ait Bulgular

\begin{tabular}{|c|c|c|}
\hline Tema & Alt tema & Kodlar \\
\hline \multirow{19}{*}{ Olumlu yön } & Etkinlikler & Öğretmen tarafından sağlanan etkinlikler \\
\hline & & Uygulamadaki etkinlikler \\
\hline & Uygulamaya ait içerik & Eğitici içerikler \\
\hline & & İlgi çekici, eğlenceli görseller ve videolar \\
\hline & & Okuma uygulamaları \\
\hline & & Eğitici oyunlar \\
\hline & Eğitimde teknoloji kullanımı & Eğitime destek \\
\hline & & Eğitim ve teknoloji entegrasyonu \\
\hline & Eğitsel imkanlar & Anlaşılması kolay \\
\hline & & Tekrar yapma imkânı \\
\hline & & Ders takibi \\
\hline & & Canlı derse katılım \\
\hline & Etkili iletişim & Öğretmenle iletişim-etkileşim \\
\hline & & Ödev kontrolü \\
\hline & & Geri dönüt alabilme \\
\hline & Düzey ölçme & Seviye belirleme \\
\hline & & Öğrenci seviyesine uygun \\
\hline & Diğer & Sosyal medyadan uzaklaştırma \\
\hline & & Kullanım kolaylığı \\
\hline \multirow{11}{*}{ Olumsuz yön } & & Hiç-yok \\
\hline & Teknik sorunlar & Teknik açıdan sorun yaşıyorum \\
\hline & & Bağlantı kesilmesi-kopması \\
\hline & & Sistemden atma \\
\hline & & Donma-yavaşlama \\
\hline & & Ses ve görüntü kalitesi düşük \\
\hline & Eğitsel açıdan sorunlar & Sikıc1 \\
\hline & & Aynı şeylerin sık tekrarı \\
\hline & & Monotonluk \\
\hline & & Yetersiz eğitici içerik \\
\hline & Bağımlılık & Ekran bağımlılı̆̆ \\
\hline
\end{tabular}

Tablo 9'a bakıldı̆̆ında uzaktan eğitim sürecinde kullanılan EBA uygulamasının veli görüşlerine göre olumlu ve olumsuz yönlerine değinilmiştir. Uygulamanın olumlu yönlerini etkinlikler, uygulamaya ait içerikler, eğitimde teknoloji kullanımı, eğitsel açıdan uygulamanın sağladığı imkanlar, etkili iletişim, öğrenci düzey ölçme şeklinde alt temalar oluşturularak kategorize edilmiştir. Bunun yanında EBA uygulamasının çocukları sosyal medyadan uzaklaştırdığı ve kullanım kolaylığı sağladığı veliler tarafından ifade edilen olumlu özellikler içerisinde yer almaktadır. Veli görüşlerine göre en sıklıkla bahsedilen olumlu özellikler arasında uygulamanın canlı derslere katılma imkânı sağlaması ve öğretmenler tarafından çocuklara etkinlikler gönderilebilmesi olarak karşımıza çıkmaktadır. Devamında uygulamada bulunan eğitici, ilgi çekici, eğlenceli görsel ve videolar, okuma uygulamaları ve çeşitli eğitsel oyunlar gibi etkinliklerin de olması veliler tarafından olumlu görülmektedir. Ayrıca kullanılan bu uygulamaların çocukların seviyesine uygun olduğu ve onların seviyelerini ölçerek ailelere de geri bildirim sağladığı belirtilmiştir. Velilere göre EBA uygulamasının uzaktan eğitimde kullanılması teknoloji ile eğitimin bir arada çalışmasını ve teknolojinin eğitime destek olmasını sağlamıştır. Veliler bu uygulamanın çocuklara ders takibi ve ders tekrarı gibi imkanlar sağladığı ayrıca uygulama içeriği sayesinde çocukların daha kolay anladıklarını ifade etmişlerdir. Veliler EBA uygulamasının öğretmenle etkili iletişim kurma, ödev kontrolü yapma ve bu sayede geri dönüt alabilme imkânı sağladığını ifade etmişlerdir. İlkokul başlangıcında uzaktan eğitim sürecinde kullanılan EBA uygulamasının olumlu yönlerine ait örnek veli görüşleri aşağıda yer almaktadır.

‘Bence kötü bir uygulama değil. Çocuğum EBA uygulamasında bulunan içeriklerden yararlanmaktadır. EBA sayesinde çocuğum çeşitli oyunlar oynuyor, eğitici videolar izliyor, uygulamada bulunan kitapları okuyabiliyor ayrıca canlı derslere bağlanabiliyor. Bu sayede eğitici içeriklere daha rahat ulaşabiliyor. EBA üzerinde bulunan içerikler sayesinde çocuğum Youtube gibi diğer sosyal medya uygulamalarından uzaklaşmış oldu bu yönüyle çok faydalı olduğunu düşünüyorum.'(V15)

'Çocuğum EBA üzerinden öğretmenin gönderdiği etkinlikleri ve ödevleri takip edebiliyor. Canlı derslerde işlenen 
konuları EBA uygulamasında bulunan eğitici içerikleri takip ederek tekrar yapabiliyor. Canlı derse katılamasak bile geçmiş konuları ve öğretmenin derste kullandığı videolara ulaşarak tekrar edebiliyoruz. EBA da bulunan çeşitli okuma uygulamalarını kullanıyoruz.'(V11)

Tablo 9'da uygulamada velilerin olumsuz olarak görüş belirttiği alanlara baktığımızda velilerden 6'sının çok memnun olduğunu hiçbir olumsuz yön belirtmediği görülmektedir. Diğer velilerin görüşlerine göre teknik sorunlar, eğitsel açıdan yaşanan sorunlar ve bağımlılık kapsamında 3 alt tema oluşturulmuştur. Velilerin sıklıkla bahsettiği olumsuzluk EBA uygulamasında teknik açıdan sıkıntı yaşamaları ve bağlantı kesilmesi, kopmalarının olduğu görülmektedir. Devamında sistemden atma, donma ve yavaşlama, ses ve görüntü kalitesinin düşük olması gibi olumsuzluklarda belirtilmiştir. Eğitsel açıdan yaşanılan olumsuzluklara bakıldığında bazı veliler yetersiz eğitsel içeriğe sahip olduğunu, sıkıcı ve monoton olduğunu, aynı şeylerin sık sık tekrarlandığını ifade etmişlerdir. Bununla birlikte diğer bir olumsuzluk olarak çocukların ekrana çok maruz bırakılması sonucunda ekran bağımlılığı geliştirdikleri veli görüşleri arasında belirtilmiştir. İlkokul başlangıcında uzaktan eğitim sürecinde kullanılan EBA uygulamasının olumsuz yönlerine ait örnek veli görüşleri aşağıda yer almaktadır.

‘EBA uygulamasında teknik sıkıntılar yaşıyoruz. Bağlantı kesilmeleri ve kopmalar oluyor bazen hiç bağlanamıyoruz. Ayrıca uygulamada bulunan etkinlikler ve videolar aynı şeyleri tekrar ediyor bence bu nedenle çocuğum bazen sıkılabiliyor.'(V16)

'Eba üzerinden gönderilen etkinlikler bazen açılmıyor. EBA 'ya girmeye çalıştığımızda bizi sistemden atıyor ve teknik sıkıntılar yaşıyoruz. Bazı zamanlarda içeriğin çok monoton ve sıkıcı gittiğini düşünüyorum.'(V3)

Tablo 10. İlkokul Başlangııında Uzaktan Eğitim Sürecinde Kullanılan EBA Uygulamasının Daha Etkili ve Faydah Olabilmesi İçin Görüş ve Önerileriniz Nelerdir? Sorusuna Ait Bulgular

\begin{tabular}{ll}
\hline Tema & Kodlar \\
\hline & Yok-hiç(memnunum) \\
& İçeriğin çeşitlendirilmesi \\
& Eğlenerek öğrenme etkinlikleri \\
& Görsellerin artması \\
& Dikkat çekici içerik ve etkinliklerin artması \\
& Okumaya teşvik \\
& Teknik anlamda iyileştirme \\
& Ders sürelerinin artması \\
\hline
\end{tabular}

Tablo 10'da velilerin EBA uygulamasının daha etkili ve faydalı olabilmesi için görüş ve önerilerine bakıldığında memnun olduklarını ifade ederek hiç öneri belirtmeyen görüşler bulunmaktadır. Diğer yandan veliler tarafından en sıklıkla dile getirilen öneri olarak ise içeriğin çeşitlendirilmesi, teknik olarak iyileştirilmelerin yapılması ve eğlenerek öğrenme etkinliklerinin artıılması gelmektedir. Ayrıca görsellerin, dikkat çekici içerik ve etkinliklerin artırılması, okumaya teşvik edici uygulamaların çoğalması ve ders sürelerinin artması da velilerin önerileri arasında bulunmaktadır. EBA uygulamasının daha etkili ve faydalı olabilmesi ile ilgili örnek veli görüşleri aşağıda yer almaktadır.

\footnotetext{
'Eğlenceli ve dikkat çekici aktivitelerin artırılması daha güzel olabilir. Daha çok oyun ve yarışmalar kullanılarak eğlenerek öğrenme sağlanabilir. Bu sayede çocukların sıkılmalarını engellemiş oluruz. Ayrıca teknik olarak ses ve görüntü kalitesi daha çok iyileştirilebilir. EBA üzerinde yapılan derslerin sürelerinin artırılması gerektiğini düşünüyorum.'(V1) 'EBA uygulaması için daha ne yapılabilir bilemiyorum çünkü şu an ki hali ile çok yeterli ve gayet memnunum.'(V19)
}

Tablo 11. İlkokul Başlangıcında Uzaktan Eğitim Sürecinde Kullanılan Zoom Uygulamasının Olumlu ve Olumsuz Özellikleri Nelerdir? Sorusuna Ait Bulgular

\begin{tabular}{lll}
\hline Tema & Alt tema & Kodlar \\
\hline & Ders şekli ve zamanı & Canlı ders \\
& & Ekstra ders ayarlama (Ek ders) \\
& Sinıf ortamı & Esnek ders zamanı ayarlama \\
Olumlu yön & Sanal sinıf \\
& Etkili iletişim & Çok kişiye ulaşabilme (çoklu sinıf) \\
& Yüz yüz iletişim \\
& Öğretmenle iletişim \\
& Anında dönüt düzetme \\
\hline
\end{tabular}




\begin{tabular}{|c|c|c|}
\hline & & Ödev kontrolü \\
\hline & Akran iletişimi & Arkadaşla etkileşim \\
\hline & & Sosyalleşme-kaynaşma \\
\hline & & Akran öğretimi \\
\hline & Başarılı teknik altyapı & Teknik olarak sorunsuz \\
\hline & & Kesintisiz bağlanma \\
\hline & & Kaliteli ses ve görüntü \\
\hline & Ölçme imkanı sağlama & Sinav yapma \\
\hline & Diğer & Okul ile bağ kurma (okul disiplini) \\
\hline & & Eğitimde süreklilik \\
\hline & & Aile desteği (ders esnasında) \\
\hline & & Erişim kolaylığg \\
\hline & & Yok-hiç \\
\hline & Teknik olumsuzluklar & Teknik sıkıntılar \\
\hline & & Bağlantı hatası (kopması, kesilmesi) \\
\hline & & Ses ve görüntüde kopma \\
\hline & & Dersten atma \\
\hline & & Giriş linki bozuk \\
\hline Olumsuz yön & Kullanıma ait olumsuzluklar & Şifre ile girmek zor \\
\hline & & Proğram dili (İngilizce) \\
\hline & & $\begin{array}{l}\text { Ekranda bütün katılımcıların aynı anda } \\
\text { görïlememesi }\end{array}$ \\
\hline & & Katılımcıların görüntüleri küçük \\
\hline & Ders saati & Bir ders süresi yetersiz \\
\hline
\end{tabular}

Tablo 11'e bakıldığında ilkokul başlangıcında uzaktan eğitim sürecinde kullanılan Zoom uygulamasının veli görüşlerine göre olumlu ve olumsuz yönlerine değinilmiştir. Uygulamanın olumlu yönleri ders şekli ve zamanı, sınıf ortamı, etkili iletişim, akran iletişimi, başarılı teknik altyapı ve ölçme imkânı sağlama olarak 6 tema altında kategorize edilmiştir. Bu temaların dışında kalan Zoom uygulamasının olumlu yönlerine bakıldığında ise okul ile bağ kurarak okul disiplini kazanma, eğitimde süreklilik sağlama, dersler sırasında ailelerin çocuklarına aile desteği sağlayabilmesi ve en sıklıkla ifade edilen görüş ise erişim kolaylığı sağlaması olmuştur. Bunların yanında bütün veliler Zoom uygulamasının en büyük öneminin canlı derslerin yapılabilmesi olduğunu belirtmişlerdir. Devamında canlı dersler sayesinde sanal sınıf ve çoklu sınıf ortamı oluşturulabildiği gibi çocukların öğretmen ve arkadaşları ile yüz yüze iletişim imkânı sağlayabilmesi de çoğu veli tarafından olumlu özellik olarak ifade edilmiştir. Ayrıca veliler bu uygulama sayesinde çocukların öğretmen ve arkadaşlarından dönütler alarak hem akran öğrenmesi sağlayabildiğini hem de sosyalleşmelerine katkı sağladığını belirtmişlerdir. Bunun yanında uygulamanın teknik olarak sorunsuz, kaliteli ses ve görüntünün yanında kesintisiz bağlanma sağladığı da velilerin görüşleri arasındadır. Zoom uygulaması ile çocukları sınav yaparak ölçme imkânı olması da veliler tarafından olumlu özellik olarak görülmektedir. Zoom uygulamasının olumlu yönlerine ait örnek veli görüşleri aşağıda yer almaktadır.

\footnotetext{
'Zoom uygulaması ile kolayca canlı derslere katılabiliyoruz. Teknik olarak gayet başarılı olduğunu düşünüyorum çünkü derslere girişte herhangi bir kesinti yaşamadan rahatça girebiliyorum. Ses ve görüntü kalitesinin güzel olduğunu düşünüyorum. Bu uygulama ile yapılan dersler sayesinde çocuğum öğretmen ve arkadaşlarını rahatça görebiliyor, onlarla iletişim kurabiliyor, derslere aktif olarak katılabiliyor. Sanki sınıf ortamında ders işleniyormuş gibi oluyor. '(V17) 'Zoom sayesinde canlı derslere öğretmenin gönderdiği linke tıklayarak kolayca katılabiliyoruz. Yapılan canlı dersler sayesinde çocuğum öğretmenini ve arkadaşlarını görerek onlarla yüz yüze iletişim kurabiliyor. Bir nebze Zoom sayesinde uzaktan da olsa sınıf ortamını yaşayabiliyor.'(V18)
}

Tablo 11'in devamında Zoom uygulamasının olumsuz yönlerine bakıldığında ise olumsuz yönü olmadığını memnun olduklarını ifade eden veli görüşleri bulunmaktadır. Olumsuz yönleri olduğunu düşünen velilerin görüşleri ise teknik olumsuzluklar, uygulama kullanımına ait olumsuzluklar ve ders saatine bağlı olumsuzluklar şeklinde 3 alt tema altında kategorize edilmiştir. Veliler tarafından en sık dile getirilen olumsuzluk ise teknik sıkıntıları kapsamaktadır. Uygulamanın bağlantı hatası verdiği, ses ve görüntüde kopmalar yaşandığı, dersten atma ve uygulamaya girerken kullanılan giriş linklerinin bozuk olduğu şeklinde velilere ait olumsuz görüssler mevcuttur. Velilerden bazıları uygulama ile her defasında derse girerken şifre kullanmanın zor olduğunu, program dili İngilizce olduğu için anlamakta zorlandıklarını, ders esnasında katılımcıların görüntülerinin küçük olduğunu ve hepsinin birden aynı anda görülemediği için çocuklarının 
arkadaşlarını ve öğretmenini görmede zorluk yaşadığını belirtmişlerdir. Ayrıca bir ders saatinin hemen dolduğunu ve çocuklarına yetersiz geldiğini ifade eden veli görüşüne de rastlanmaktadır. Zoom uygulamasının olumsuz yönlerine ait örnek veli görüşleri aşağıda yer almaktadır.

'Zoom uygulaması üzerinden canlı derslere katıldığımızda teknik sıkıntılar çok yaşıyoruz. Örneğin bazen sistem bizi dersten atıyor, ses ve görüntüde kopmalar yaşıyoruz. Ayrıca link üzerin Zoom uygulamasına giriş yaparken zorlanıyoruz ve bazen linkler çalışmıyor.'(V19)

'Uygulamada teknik sıkıntılar yaşıyoruz. Bazen mikrofondan ses gitmiyor, görüntü donuyor veya bizi dersten atıyor.

Ayrıca uygulama dili İngilizce olduğu için kullanmak zorlaşıyor.'(V3)

Tablo 12. Ilkokul Başlangıcında Uzaktan Eğitim Sürecinde Kullanılan Zoom Uygulamasının Daha Etkili ve Faydalı Olabilmesi İçin Görüş ve Önerileriniz Nelerdir? Sorusuna Ait Bulgular

\begin{tabular}{ll}
\hline Tema & Kodlar \\
\hline & Yok-hiç \\
& Teknik olarak iyileştirilebilir \\
& Türkçe dil seçeneği \\
& Bir ders süresinin artması \\
Öneriler & Bütün katılımcıların ekranda aynı anda görünebilmesi \\
& Öğrencilerin ekran paylaşabilmesi \\
& Öğrencilerin öğretmenden bağı̆msı giriş yapabilmeleri \\
& Katılımcı görüntülerinin büyümesi \\
\hline
\end{tabular}

Tablo 12'de Zoom uygulamasının daha etkili ve faydalı olabilmesi için veli görüş ve önerilerine yer verilmiş. Bu tablodan yola çıkarak velilerin yarısından fazlası (11 veli) hiçbir öneride bulunmayarak su anki hali ile gayet memnun olduklarını dile getirmişlerdir. Geri kalan veliler ise sıklıkla teknik olarak uygulamanın daha çok iyileştirilebileceğinden bahsetmişlerdir. Bununla birlikte veliler Türkçe dil seçeneği olmasını, ders sürelerinin arttırılması gerektiğini, öğrencilerin öğretmenden bağımsız olarak uygulamaya giriş yapma imkânı sağlanmasını, öğrencilerin rahatlıkla ekran paylaşımı yapabilmesini, bütün katılımcıların aynı anda ekranda görüntülenebilmesini ve bu görüntülerin büyümesini istediklerini ifade etmişlerdir. Zoom uygulamasının daha etkili ve faydalı olabilmesi ile ilgili örnek veli görüşleri aşağıda yer almaktadır.

\footnotetext{
'Uygulamada yaşanılan teknik sıkıntıların iyileştirilebileceğini düşünüyorum. Donma ve kesilmelerin düzeltilmesi gerekiyor. Ayrıca uygulama dili İngilizce olduğu için anlamakta zorlanıyorum bu nedenle uygulamaya Türkçe dil seçeneğinin getirilmesi kullanım açısından daha kolay olurdu. '(V3)

'Ders saatleri 30 dakikadan daha uzun olmalı. 45 dakika ders yapılsa daha etkili olacağını düşünüyorum. Çünkü öğretmenin bağlanması, çocukların gelmesi derken zaten ders süresinin bir bölümü gidiyor. Çocuklar derse tam adapte oluyorlar bu seferde ders süresi bitiyor.'(V16)
}

\section{Sonuç, Tartışma ve Öneriler}

$\mathrm{Bu}$ araştırmada pandemi başlangıcıyla birlikte uzaktan eğitime geçilmesi, bu süreçte çocukların okul öncesi eğitimi tamamlaması ve daha sonra da ilkokula başlaması incelenmiştir. Araştırmadan elde edilen sonuçlarla pandemi başlangıcında uzaktan eğitime geçilmesiyle okul öncesi dönem çocukların yarısından fazlasının uzaktan eğitime katılmadığı, yapılan uzaktan eğitimin ise veliler tarafından yetersiz görüldüğü ortaya koyulmuştur. Pandemi sürecinde okul öncesi eğitimden ilkokula geçerken uzaktan eğitime hiç katılamayan çocukların dışında genel olarak çocukların telefon üzerinden öğretmenin gönderdiği etkinlikler, EBA uygulamasında bulunan etkinlikler ve Zoom uygulamasını kullanarak uzaktan eğitime katıldıkları sonucuna ulaşılmıştır. Süreçte canlı derslerin fazla kullanılmadığı görülmüştür. Göktaş ve diğerleri'ne (2020) göre okul öncesi çocuklarının sadece $\% 52$ 'sinin uzaktan eğitime katılabildikleri belirtilmiştir. Bu kapsamda bunun nedeni olarak uzaktan eğitime çok ani geçiş olması ve öğretmenlerin kendilerini yetersiz görmeleri gösterilebilir (Demir ve Kale, 2020). Bununla birlikte EBA uygulamasının anaokulu düzeyinde uzaktan eğitimde kullanılmaya başlanması salgın dönemi ile gerçekleşen bir durumdur. Mili Eğitim Bakanı Ziya Selçuk 12.10.2020 tarihinde uzaktan eğitimin bir parçası olarak TRT EBA açılışını gerçekleştirmiştir (Aktaş, 2020). TRT EBA anaokulunun açlışı sonrası geçen 3 haftalık sürede ise okul öncesi kademesinde 18717 ders saati canlı ders yapıldığı açıklanmıştır (MEB, 2020c). EBA uygulamasının diğer eğitim kademelerine göre okul öncesinde daha geç kullanılmaya başlanması öğretmenlerin yeterli bilgi ve beceriye sahip olmadığını da göstermektedir (Akkaş Baysal ve diğerleri, 2020). Okul öncesi dönemde yapılan uzaktan eğitim sürecinde 
çoğunluğu anneler oluşturmak üzere, baba ve evde bulunan büyük kardeşlerin okul öncesi dönemindeki çocuklara yardımda bulundukları sonucuna ulaşılmıştır. Bulgulardan yola çıkarak annelerin yarısından fazlasının çalışmıyor ve ev hanımı olmaları nedeniyle çocukları ile ilgilenebilecek baba ve kardeşlere oranla daha çok zamanları olduğu sonucuna ulaşılabilir. Okul öncesi eğitimden ilkokula geçiş sürecinin uzaktan eğitim yolu ile olması ise veli desteğine olan ihtiyacı ve gerekliliği daha çok artırmıştır. Kuzu (2020) velilerin uzaktan eğitim çalışmalarını yakından izlediğini ve pandemi sürecinde çocuklarını destekleme çabasında olduklarını belirtmiştir. Brandes ve diğerleri (2007)'nin özel gereksinimli öğrenciler ile yaptıkları çalışmada okul öncesi dönemden ilkokula geçiş süreci için velilerin eğitim öğretim sürecine dahil edilmesinin çok önemli olduğuna değinilmiştir. Yazıcı, Nazik Kumbasar ve Akman'ın (2016) ailelerin gözünden ilkokula geçiş sürecini araştırdıkları çalışmada, ilkokula geçiş sürecinin çocuklar kadar aileler için de zor bir dönem olduğu, ev rutinlerinin değiştiği ve ailelerin süreçte çocuklarının yaşadıkları zorluklara da şahit oldukları vurgulanmıştır.

Uzaktan eğitim ile gerçekleştirilen okul öncesi eğitiminde öğretmenin gönderdiği etkinlikler dişında çoğunlukla velilerin evde kendi oluşturdukları etkinlikleri kullandıkları görülmüştür. Akkaş Baysal ve diğerleri (2020) yaptıkları çalışmada uzaktan eğitim sürecinde okul öncesi eğitim için sağlanan içeriklerin çocukların akademik, duygusal ve sosyal gelişimlerini destekleyecek materyal ve içerik yönünden eksik olduğunu tespit etmişlerdir. Buradan yola çıkarak okul öncesi dönemde sadece öğretmenin gönderdiği etkinliklerin yetersiz olduğunu ve velilerin de evde kendi çabaları ile çocuklarına yararlı olabilecek çeşitli etkinliklerle uzaktan eğitim sürecine destek vermeleri gerekmektedir. Bu süreçte okul öncesi eğitimi ile ilgili evde kendilerinin hiçbir etkinlik yapmadıklarını belirten veliler de bulunmaktadır. Erden ve Altun (2014) okul öncesi eğitimi alan çocuğun okul öncesi eğitim almayan çocuğa göre ilkokula daha hazır geldiği uyum konusunda az sıkıntı çektiği ve ilköğretime geçtiğinde sosyal anlamda daha açık olduğunu söylemektedirler (Erkan ve Kırca, 2010). Bu kapsamda bu süreçte evde velilerin yaptırdıkları çeşitli etkinlikler çocukların ilkokula daha rahat geçiş yapmasını ve daha kolay uyum sağlamalarına yarayacaktır. Bazı veliler Türker ve Dündar (2020)'ın pandemi sürecinde yapılan uzaktan eğitim yüz yüze eğitime tek alternatif olduğu düşüncesini desteklerken, bazıları da Erol ve Erol (2020)'un ilkokul öğrencileri için uzaktan eğitimin yüz yüze eğitim kadar etkili olmadığı ve uzaktan eğitimin ilkokul öğrencileri için uygun olmadığı düşüncelerini destekler nitelikte görüş bildirmişlerdir. Okul öncesi eğitimde ise öğretmenin veliler aracılığıyla yaptığı etkinlik paylaşımları ve canlı dersler ile yapılan uzaktan eğitim sayesinde öğretmenin çocuklarla ilgilenebildiğini ve çocukların okul ile bağ kurabildiklerini belirtmişlerdir. Ancak, uzaktan eğitimin okul öncesi ve ilkokul kademelerine uygunluğu ve sağladığı faydanın öğretmen yeterlilikleri, teknolojik imkanlar, velilerin sosyo-ekonomik düzeyleri gibi çeşitli faktörlerden etkilenebileceği göz önünde bulundurulmalıdır. Ayrıca, yürürlükte olan okul öncesi eğitim programının esnek yapısı uzaktan eğitime uygun olabilirken, ilkokul müfredatının bazı eksikliklerinin uzaktan eğitimden faydalanılmasında engel oluşturabileceği belirtilmektedir (Koç, 2021).

Veliler uzaktan eğitimle yapılan okul öncesi eğitimin çocukların eğitsel ve sosyal açıdan olumsuzluklar yaşandığı belirtmişlerdir. Gülay Ogelman ve diğerleri (2021) okul öncesi çocuklarının okula uyum süreçlerini incelediklerinde çocuklarda çeşitli sosyal davranış sorunları yaşandığı ve öğrenilen bilgilerin unutulması gibi çeşitli sorunlarla karşılaşıldığı görülmüştür. Bu süreçte uzaktan eğitim olması nedeniyle çocukların yeterince sosyalleşemediği ve özgüven kazanamadıkları görülmüştür. Çalışma bulgularına göre ailelere çok fazla iş yüklendiğini, çocukların ekran ve teknoloji bağımlılığı geliştirdiklerini ve öğretmen ile öğrenci arasında çeşitli iletişim sıkıntılarının olduğu bulunmuştur. Yaşanılan iletişim sorunları ilkokula hazırbulunuşluk düzeyinde çocuklarda büyük eksik ve olumsuzluklara sebep olabileceği Vecchia (2011) tarafından ifade edilmiştir. Erol ve Erol'un (2020) yaptıkları çalışmada da çocukların uzaktan eğitim ile ilkokula başlama sürecinin yaşanması nedeniyle çocukların sosyal ilişkilerin olumsuz etkilenmesi ve okuldan tamamen soğuyarak uzaklaşması gibi durumların gerçekleştiği ayrıca öğretmenin çocuklarla doğrudan iletişim kurmasının çocukları mutlu ve motive ettiğini, süreçte dijital araç kullanımında artış olduğu ve velilerin çocuklarının eğitiminde çokça yer almaya başladıkları belirlenmiştir.

Uzaktan eğitim ile ilkokula geçiş sürecinin daha etkili ve faydalı olabilmesi için veliler canlı derslerin 
artırılarak etkili ve kaliteli dersler işlenmesi gerektiğini, uzaktan eğitimin tek başına değil yüzyüze eğitime destek olacak şekilde yapılarak hibrit eğitim modelinin daha faydalı olacağını ifade etmişlerdir. Yılmaz ve diğerleri (2020) de yaptıkları çalışmada hibrit eğitimin veliler tarafından istendiğini ifade etmişlerdir. Bir başka öneri ise bu süreçte etkili iletişimin sağlaması yönündedir. Brandes ve diğerleri'ne (2007) göre ilk okula başarılı bir geçiş sağlamak için öğretmen öğrenci arasındaki ilişki ve iletişim çok önemlidir. Bu bağlamda uzaktan eğitim sürecinde iletişim konusu üzerinde çok da durulması gereken bir konudur. Ayrıca veliler ilkokula geçişte uzaktan eğitim sürecinde öğretmen ile olan ilgi ve iletişim eksikliği, ilkokula geçiş aşamasında olan çocukların küçük yaşta olmaları nedeniyle kendi öğrenme sorumluluklarını alamadıkları için ailelerin evlerinde çocuklarına bir nevi öğretmenlik yapmaları- ve süreçte çocukları ile yalnız bırakılmaları gibi nedenlerle kendilerine çok sorumluluk düştüğünü belirterek desteğe ihtiyaç duyduklarını ifade etmişlerdir. Erol ve Erol (2020) velilerin uzaktan eğitim sürecinde bazı zamanlarda kendilerini yetersiz hissettikleri belirlenmiştir. Bu nedenle süreç içinde desteğe ihtiyacı olan ailelere yeterli desteğin verilmesi çok önemli olarak görülmektedir.

Uzaktan eğitim sürecinde kullanılan uygulamalar arasından en az kullanıma sahip olan TRT Okul (EBA) platformu olduğuna ulaşılmıştır. Bunun nedeni olarak çocukların çevrimiçi derslerle ve ödevlerle gün içerisinde fazla meşgul olması ve TRT Okul (EBA) izlemeye zamanlarının kalmamasını az kullanım nedeni olarak düşünülebilir. Televizyon aracıllı̆̆ ile asenkron yapılan uzaktan eğitimin canlı derslere katılma imkânı olmayan veya herhangi bir sebeple canlı dersleri kaçıran çocukların ders ve konuları takip ederek tekrar yapabilmelerine olanak sağlamış olması senkron derslere alternatif sunmuştur. Buradan hareketle TRT uygulamaları sayesinde eğitime erişim sağlayamayan çocuklara eğitim ulaştırma imkânı bularak fırsat eşitliği sağlanmış olmaktadır. Uzaktan eğitim de kullanılan EBA ve Zoom gibi uygulamaları senkron eğitim yapmada en çok kullanılan uygulamalar arasındadır. Uzaktan eğitim sürecinde yapılan senkron dersler bulgulara göre birçok kişiye aynı anda ulaşma imkânı sağlamanın yanında en sıklıkla ifade edilen şekliyle öğretmen ve öğrencilere sanal sınıf oluşturma konusunda çok faydalı olmuştur. Yapılan canlı dersler ve sanal ortamlar sayesinde eğitimde süreklilik sağlamış olmaktadır. Senkron şeklinde yapılan derslerin öğretmen, öğrenci ve akranlar arasında etkili iletişim sağlama imkânı verebilmesinin önemi ifade edilmiş ayrıca ailelerin çocuklarının yanında bulunarak bu süreçte onlara destek olma imkanı sağladığı ifade edilmiştir. Günbaş ve Gözüküçük'e (2020) göre öğretmenler pandemi sürecinde öğrenci ve ailelere destek olmak amaciyla ödev verme, ses, görüntü, video etkinlikleri gönderme çabasıyla öğrenci ve velilerle sürekli iletişim sağlama çabasındadırlar. Senkron derslerin çocuk ile okul arasında bir köprü vazifesi gördüğü belirtilerek okul ile bağ kurabilme noktasında kilit rol oynadığı ve çocukların uzaktan da olsa okul disiplinine sahip olmasını sağladığı ifade edilebilir. Uzaktan eğitimde kullanılan uygulamaların çeşitli içerikler barındırması ve bu içeriklerin çocuklara çeşitli faydalar sağladığı veliler tarafından ifade edilmiştir. Koçdar, Karadeniz, Bozkurt ve Büyük 'ün (2017) de bahsettiği üzere kullanılan içerikler eğlenerek öğrenme sağlanarak uzaktan eğitimi daha verimli hale getirebilirler ayrıca çocukların daha kalıcı ve etkileşimli öğrenmesini sağlayabilir. Pandemi sürecinde uzaktan eğitime geçilmesi ile birlikte eğitimde teknoloji kullanımı kaçınılmaz olmuştur. Bu kapsamda veliler kullanılan uygulamalar ile eğitim ve teknoloji entegrasyonunun sağlandığını ve teknoloji ile eğitime destek verildiğini belirtmişlerdir. Ayrıca uygulamaların teknik olarak sorunsuz olduğu, kullanımın kolay olması ve erişim kolaylığı sağlaması olumlu düşünceler arasında bazı veliler tarafından ifade edilmiştir. Şentürk'ün (2020) de bahsettiği üzere üst düzey teknoloji bilgisi gerektirmeyen uzaktan eğitim uygulamalarının kullanımında velilerin zorlanmadıklarını ve kullanımın kolay olduğu belirtilmiştir. Buna karşın bazı veliler ise kullanılan uygulamalar ile uzaktan eğitime katılım sırasında en çok çeşitli teknik sıkıntılar (bağlantı kopması, dersten atma vb...) yaşandıklarını ifade etmişlerdir. Bunun nedeni olarak velilerin bulunduğu yerde internetin çekmesinde sıkıntıların yaşanması veya uygulamaya girenlerin yoğunluğu gösterilebilir.

Senkron derslere katılım sırasında uygulama dilinin Türkçe olmaması ve ders sırasında ekranın küçük kalması gibi olumsuzluklar ifade edilmiştir. Bunun nedeni ise bulgularda ifade edildiği üzere velilerin uzaktan eğitim sürecinde en çok akıllı telefonlar kullandıkları ve akıllı telefonların ekranlarının küçük olması nedeniyle görüntülerin net olmaması veya görüntülerin olduğundan daha küçük görünmesine neden olduğu söylenebilir. Bununa birlikte veliler asenkron uygulamalar (EBA, TRT) üzerindeki etkinlik ve içeriklerini genel anlamda yetersiz bulduklarını, sıkıcı ve aynı şeylerin sık sık tekrarlandığını için monoton olduğunu ve tek 
düze anlatıma sahip olduğunu ifade etmişlerdir. Alan yazına bakıldığında Günbaş ve Gözüküçük (2020) çocukların EBA uygulamasını kullanımı sırasında teknik sıkıntılar yaşandığını, dikkatlerinin dağıldığını, isteksiz olduklarını ve sıkıldıklarını belirtmişlerdir. Veliler çocuklarının uzun saatlerce EBA üzerinden senkron ve asenkron olarak uzaktan eğitime katılım sağlamaları sebebiyle çocuklarında ekran bağımlılığı geliştiğini ifade etmişlerdir. TRT kanalları aracılığı ile yapılan uzaktan eğitimde çocuklarının öğretmenle iletişim kurma imkânı olmadığı için iletişim sıkıntısı yaşandığı vurgulanmıştır. İletişim sıkıntısının nedeni televizyon üzerinden yapılan yayınların ve ders anlatımlarının sadece öğretmenden öğrenciye olacak şekilde tek taraflı etkileşime neden olması olabilir ve bu durum öğrencilerin dikkat sürelerini kısaltarak dersten kopmalarına neden olabilir.

Uzaktan eğitim sürecinde kullanılan uygulamaların etkili ve faydalı olması yönünde veli önerilerine bakıldığında çoğu veli uygulamalardan memnun kaldıklarını ifade ederken bazı veliler bu uygulamaların içeriklerinin zenginleştirilerek daha eğlenceli ve dikkat çekici içeriklerin eklenmesi gerektiğini bunun yanında uygulamalardan kaynaklanan teknik sorunların giderilerek teknik iyileştirme yapılmasını, bir ders saatinin çocuklarına yetersiz geldiği için artırılmasını ve daha kaliteli anlatım yapılmasını önermişlerdir. Canlı(senkron) dersler sırasında bütün katılımcıların aynı anda ekranda görülebilmesini ve görüntülerinin daha büyük olmasını, öğrencilerin öğretmenden bağımsız olarak uygulamaya giriş yapabilmelerini ve öğrencilerin ekran paylaşımı yapmasını istedikleri şeklinde öneriler ifade edilmiştir. Çubukçu ve Aktürk'e (2020) göre Zoom uygulaması ile yapılan senkron eğitimde öğretmen ve öğrenciler ses, görüntü ve ekran paylaşımları yapabilmektedir. Buradan hareketle velilerin böyle bir öneri sunmasının nedeni olarak velilerin Zoom uygulamasının teknik özelliklerine tam olarak hâkim olmamaları ve uygulama özelliklerini kullanma konusunda yetersiz oldukları sonucuna ulaşabiliriz. Buradan hareketle velilere Zoom uygulaması ile ilgili çeşitli eğitim ve bilgilendirmelerin yapılarak destek olunması gerekmektedir.

Okul öncesi eğitimi çocukların hayatlarının en önemli adımı olarak görülmektedir. Okul öncesinde alınan eğitim çocukların ileriki eğitim hayatlarının temeli oluşturmaktadır. Bu süreçte iyi ve yeterli bir eğitim alarak ilk okula geçiş yapmak sadece çocukların değil öğretmen ve velilerin de ilkokula geçiş sürecini daha rahat atlatmalarını sağlayacaktır. Bu geçişi sağlamak pandemi dönemine denk geldiği için uzaktan eğitim ile olmak zorunda kalmıştır. Uzaktan eğitim sürecine sadece çocuklar değil velilerde aktif olarak katılmaktadır. Bu nedenle velilerin uzaktan eğitim uygulamaları sırasında yaşadıkları deneyimler ve oluşan istek ve ihtiyaçları göz önünde bulundurulmuştur. Bu kapsamda uzaktan eğitimin daha verimli ve kaliteli olmasını sağlamak için velilerin görüş ve önerilerinin dikkate alınması büyük önem taşımaktadır. Çalışma bulgularına bakıldığında velilerin ve öğrencilerin okul öncesinden ilk okula geçiş aşamasında uzaktan eğitim sürecinde çeşitli zorluklar yaşadığı ortaya çıkmıştır. Eğitimin tüm paydaşlarının yararına olması açısından ilkokula geçiş sürecinin daha iyi ve kaliteli bir şekilde geçirilmesi gerektiği vurgulanmıştır. İlkokul öğretim programlarının uzaktan eğitime uygunluğu incelendiğinde programlarda yer alan kazanımların büyük çoğunluğunun uzaktan eğitime uyarlanabilir olduğu görülmektedir (Koç, 2021). Ancak öğrencilerin öğrenme kayb1 yaşamamaları için bazı kazanımların gözden geçirilerek uzaktan eğitime uygun hale getirilmesi önerilmektedir. Ayrıca okul öncesi dönem eğitim hayatının temel taşıdır. Bu nedenle bu dönemde alınan eğitim kişinin bütün eğitimini etkilemektedir. Uzaktan eğitim sürecinde okul öncesi eğitimin yeterli ve kaliteli yapılması için daha çok canlı dersler yapılarak çocukların öğretmen ve akranları ile yüz yüze iletişim kurmaları yaralı olacaktır. Uzaktan eğitim sürecinden öğrenciler ile birlikte aileler de çok etkilenmişlerdir. Okul öncesi ve ilkokul çağındaki öğrencilerin yaşları küçük olduğu için süreç içinde veliler çocuklarına yol göstererek destek olmuşlardır. Bu nedenle bu süreçte sadece çocukların eğitimi ile değil ailelerinde eğitimi çok büyük önem arz etmektedir. Bu kapsamda uzaktan eğitim ile ilgili velilere çeşitli eğitimlerin ve seminerlerin verilerek onların da süreç ile ilgili doğru bilgilere sahip olması sağlanmalıdır. Öğretmen, öğrenci ve veli etkileşiminin kaliteli sağlanması önemlidir. Bu kapsamda öğretmenlerin telefon üzerinden velilerle iletişim sağlaması veya sanal ortamda yüz yüze veli toplantıları şeklinde veli bilgilendirmeleri çalışmaları yapması sağlanabilir. Ayrıca EBA platformu üzerinde velilere yönelik alanlar oluşturularak veli iletişimi ve bilgilendirilmesi sağlanabilir.

\section{Öneriler}


- Pandeminin ilk döneminde okul öncesi eğitim göz ardı edilmiştir. Bu konuda politika üretilememesinin nedenlerinden biri uzaktan eğitimin okul öncesi eğitime entegrasyonunda yaşanan problemlerdir. Bu nedenle, okul öncesi eğitimin dinamikleriyle uyumlu bir uzaktan eğitim modelinin oluşturulması elzemdir.

- Televizyon üzerinden yayın yapan TRT Okul ve EBA TV‘nin uzaktan eğitimde diğer erişim kanalları olmadığında kullanıldığı tespit edilmiştir. Bu kanalların uzaktan eğitime katkı sunması için içeriğin zenginleştirilmesi ve ders saatlerinin artırılması gerekir. Ayrıca eğitime yönelik olarak kurulan bu kanalların tanıtım yetersizliği ve öğretmenlerin öğrencileri buraya yönlendirme problemleri de giderilmelidir.

- EBA ve EBA TV platformlarında özellikle okul öncesi ve 1 . Sınıf öğrencilerinin dikkatini çekebilmek ve eğitimde kullanımını artırabilmek için eğitici ve eğlendirici özgün içeriklerin eklenmesi önerilebilir.

- Uzaktan eğitime yönelik yerli ve sınırsız erişime açık yazılımlar geliştirilmeli ve eğitim alanında kullanıma sunulmalıdır. Ayrıca Zoom gibi sanal sınıf uygulamalarına Türkçe dil desteği getirilmeli ve öğretmen, öğrenci ve velilere bu tip uygulamaların nasıl kullanacağına yönelik bilgilendirme çalışmaları yapılabilir.

- Çalışma Kayseri ilinde bulunan 20 veli ile sınırlandırılmış nitel bir çalışmadır. Bu nedenle çalışmanın farklı örneklemler üzerinde farklı yöntemler kullanılarak tekrar edilmesi hem çalışmanın güvenirliği hem de genellenebilirliği açısından önerilebilir.

\section{Yazarların Beyanı}

Araştırmacıların katkı oranı beyanı: Her iki yazar, araştırmanın giriş, yöntem, bulgular, tartışma ve sonuç bölümlerine yüzde elli oranında katkıda bulunmuştur.

Etik Kurul Kararı: Bu araştırma için Erciyes Üniversitesi Sosyal ve Beşeri Bilimler Etik Kurulu'ndan (2021-62) etik izin alınmıştır.

Çatışma beyanı: Makalenin yazarları bu çalışma ile ilgili herhangi bir çıkar çatışmasını olmadığını beyan ederler.

Destek ve teşekkür: Bu çalışmada herhangi bir kurum veya kuruluştan destek alınmamıştır.

\section{Kaynaklar}

Akkaş Baysal, E., Ocak, G., \& Ocak, İ. (2020). Covid-19 salgını sürecinde okul öncesi çocuklarının EBA ve diğer uzaktan eğitim faaliyetlerine ilişkin ebeveyn görüşleri. Uluslararası Sosyal Bilimler Ĕ̆itimi Dergisi, 6(2), 185214.

Aktaş, Y. (2020). Milli Eğitim Bakanı Selçuk: EBA TV Anaokulu açıldı. 11 Haziran 2021 tarihinde https://www.aa.com.tr/tr/egitim/milli-egitim-bakani-selcuk-eba-tv-anaokulu-acildi/2008750 adresinden erişildi.

Ansari, A., \& Pianta, R. C. (2018). The role of elementary school quality in the persistence of preschool effects. Children and Youth Services Review, 86, 120-127.

Aslan, N. \& Akın, F. (2021). Covıd-19 pandemisinde okul öncesi dönemdeki öğrencilerin uzaktan eğitimi: Bir eylem araştırması. Alanyazın-CRES Journal 2(1), 8-17.

Bakken, L., Brown, N., \& Downing, B. (2017). Early childhood education: The long-term benefits. Journal of research in Childhood Education, 31(2), 255-269.

Bozgün, K., \& Uluçınar Sağır, Ş. (2018). Okuma yazmayı öğrenme sürecinde okul öncesi eğitimin etkisi. 2. International Symposium on Innovative Approaches in Scientific Studies (ISAS 2018) içinde (s. 1110-1115), Samsun. 
Brandes, J., Ormsbee, C., \& Haring, K. (2007). From early intervention to earlychildhood programs: Timeline for early successful transitions (TEST). Intervention inSchool \& Clinic, 42(4), 204-211.

Brom, C., Lukavský, J., Greger, D., Hannemann, T., Straková, J. \& Švarí cek, R. (2020). Mandatory home education during the COVID-19 lockdown in the Czech Republic: A rapid survey of 1st-9th graders' parents. Frontiers in Education, 5(103), 1-8.

Büyüköztürk, Ş., Kılıç Çakmak, E., Akgün, Ö., Karadeniz, Ş., \& Demirel, F. (2018). Bilimsel araştırma yöntemleri. Ankara: Pegem Akademi.

Can, E. (2020). Coronavirüs (Covid-19) pandemisi ve pedagojik yansımaları: Türkiye' de açık ve uzaktan eğitim uygulamaları. $A U A d, 6(2), 11-53$.

Chang, G.C.\& Satako, Y. (2020). How are countries addressing the Covid-19 challenges in education? A snapshot of

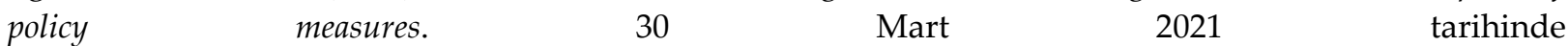
https://www.gecv.ac.in/uploads/ssip/UNESCO\%20snap\%20shot\%20for\%20maintaining\%20education.p $\underline{\mathrm{df}}$ adresinden erişildi.

Coşkunserçe, O., \& İşçitürk, G. B. (2019). Eğitim bilişim ağı (EBA) platformu hakkında öğrencilerin farkındalığının artırılmasına yönelik bir durum çalışması. Eğitimde Nitel Araştırmalar Dergisi, 7(1), 260-276.

Currie, J., \& Almond, D. (2011). Human capital development before age five. In Handbook of labor economics (Vol. 4, pp. 1315-1486). Amsterdam: Elsevier.

Çabuk, B. (2018). Okul öncesi dönemden okul dönemine geçiş. Ankara: Anı Yayıncılık.

Çubukçu, C., \& Aktürk, C. (2020). The rise of distance education during covid-19 pandemic and the related data threats: A study about Zoom. Iğdır Üniversitesi Sosyal Bilimler Dergisi, (Ek2), 127-143.

Dearing, E., McCartney, K. \& Taylor, B. (2009). Does higher-quality early child care promote low-income children's math and reading achievement in middle childhood? Child Development, 80, 1329-1349.

Demir, F., \& Özdaş, F. (2020). Covid-19 sürecindeki uzaktan eğitime ilişkin öğretmen görüşlerinin incelenmesi. Milli Eğitim Dergisi, 49(1), 273-292.

Demir, S., \& Kale, M. (2020). Öğretmen görüşlerine göre, Covid-19 küresel salgını döneminde gerçekleştirilen uzaktan eğitim sürecinin değerlendirilmesi. Electronic Turkish Studies, 15(8), 3445-3470.

Dereli, E. (2012). Okulöncesi öğretmenleri ile ilköğretim birinci sınıf öğretmenlerinin ilköğretime hazırlık süreci ile ilgili görüşlerinin karşılaştırılarak incelenmesi. Akademik Bakış Dergisi, 9 (3), 1- 20.

Dockett, S., \& Perry, B. (2001). Starting school: Effective transitions. Early Childhood Research \& Practice, 3(2), 119.

Dünya Sağllk Örgütü. (2020). WHO coronavirus disease (COVID-19) dashboard. 6 Mart 2021 tarihinde https://covid19.who.int/ adresinden erişildi.

Einarsdottir, J. (2003). When the bell rings we have to go inside: Preschool children's views on the primary school. European Early Childhood Education Research Journal, 11(sup1), 35-49.

Ekinci Vural, D. ve Kocabaş, A. (2016). Okul öncesi eğitim ve aile katılımı. Elektronik Sosyal Bilimler Dergisi, 15(59), 1174-1185

Erden, F. T., \& Altun, D. (2014). Sınıf öğretmenlerinin okul öncesi eğitim ve ilköğretime geçiş süreci hakkındaki görüşlerinin incelenmesi. Elementary Education Online, 13(2),482-502.

Erkan, S., \& Kırca, A. (2010). Okul öncesi eğitimin ilköğretim birinci sınıf öğrencilerinin okula hazır bulunuşluklarına etkisinin incelenmesi. Hacettepe Üniversitesi Ĕ̆itim Fakültesi Dergisi, 38(38), 94-106.

Erol, M., \& Erol, A. (2020). Koronavirüs pandemisi sürecinde ebeveynleri gözünden ilkokul öğrencileri. Milli Eğitim Dergisi, 49(1), 529-551. 
Göktaş, İ., Gülay Ogelman, H., \& Güngör, H. (2020, Eylül). Covıd-19 sürecinde 5-6 yaş çocuklarının online eğitim imkânlarına yönelik anne-baba görüşleri. 5. Uluslararası Bilimsel Araştırmalar Kongresi (IBAD-2020), İstanbul.

Gülay Ogelman, H., Güngör, H., \& Göktaş, İ. (2021). Covid-19 ve yeni dönemdeki okula uyum süreci: Okul öncesi eğitimi öğretmenlerinin görüşlerinin incelenmesi. International Journal of New Trends in Arts, Sports E Science Education (IJTASE), 10(1), 11-24.

Günbaş, N., \& Gözüküçük, M. (2020). Views of elementary school children's parents about distance education during the Covid-19 pandemic. Sakarya University Journal of Education, 10(3), 686-716.

Heckman, J., Pinto, R., \& Savelyev, P. (2013). Understanding the mechanisms through which an influential early childhood program boosted adult outcomes. American Economic Review, 103(6), 2052-86.

Hodges, C., Moore, S., Lockee, B., Trust, T., \& Bond, A. (2020). The difference between emergency remote teaching and online learning. Educause Review, 27, 1-12.

Johnston, J. P. (2020). Creating Better Definitions of Distance Education. Online Journal of Distance Learning Administration, 23(2), 1-6.

Kaynar, H., Kurnaz, A., Doğrukök, B., \& Şentürk Barışı, C. (2020). Ortaokul öğrencilerinin uzaktan eğitime ilişkin görüşleri. Turkish Studies, 15(7), 3269-3292.

Koç, E. S. (2021). İlkokul öğretim programlarının COVID-19 sonrası yaygınlaşan uzaktan eğitime uygunluğunun incelenmesi. International Anatolia Academic Online Journal Social Sciences Journal, 7(1), 2436.

Koçdar, S., Karadeniz, A., Bozkurt, A., \& Büyük, K. (2017). Açık ve uzaktan öğrenmede sorularla zenginleştirilmiş etkileşimli video kullanımı. Eskişehir Osmangazi Üniversitesi Sosyal Bilimler Dergisi, 18(2), 93-113.

Kuzu, Ç.İ. (2020). Covid-19 pandemisi sürecinde uygulanan ilkokul uzaktan eğitim programı (EBA TV) ile ilgili veli görüşleri. Milli Ĕ̆itim Dergisi, 49(1), 505-527.

La Paro, K., \& Pianta, R. (2000). Kindergarten teachers' reported use of kindergarten to first grade transition practices. Elementary School Journal, 101(1), 63-78.

Lincoln, Y. S., \& Guba, E. G. (1985). Naturalistic inquiry. California: Sage Publications.

Metin, Ş., \& Aral, N. (2016). Proje yaklaşımına dayalı eğitimin beş yaş (60-72 ay) çocuklarının görsel algılarına etkisinin incelenmesi. Eğitim ve Bilim, 41(186), 149-162.

Milli Eğitim Bakanlığı. (2020a). Sanal sınıfların kullanımına ilişkin yazı. 11 Haziran 2021 tarihinde http://fethiye.meb.gov.tr/meb iys dosyalar/2020 04/19120427 Sanal SYnYf.pdf adresinden erişildi.

Milli Eğitim Bakanlığı. (2020b). Küresel salgın döneminde uzaktan eğitim izleme ve değerlendirme raporu. 9 Mart 2021 tarihinde https://www.ogretmensitemiz.com/images/upload/01.pdf adresinden erişildi.

Milli Eğitim Bakanlığı. (2020c). Sayılarla uzaktan eğitim. 3 Haziran 2021 tarihinde http://yegitek.meb.gov.tr/www/sayilarla-uzaktan-egitim/icerik/3090 adresinden erişildi.

Milliyet. "Bakan Selçuk canlı yayında açıkladı! Uzaktan eğitim nasıl olacak?". 29.08.2020. 11 Haziran 2021 tarihinde $\quad$ https://www.milliyet.com.tr/siyaset/sondakika-milli-egitim-bakani-ziya-selcuktan-uzaktanegitim-aciklamasi-6292822 adresinden erişildi.

O'Connor, C., \& Joffe, H. (2020). Intercoder reliability in qualitative research: Debates and practical guidelines. International Journal of Qualitative Methods, 19, 1-13.

Oktay, A. (2003). Okul öncesinde temel kavramlar, okul öncesi eğitimin amaçları ve temel ilkeleri- özel öğretim yöntemleri. Eskişehir: Anadolu Üniversitesi Açık Öğretim Fakültesi Yayınları. 
Ozgem, K., Kan, S. G., Kuset, S., \& Şaşmacıoğlu, E. (2020). Evaluation of the effect of distance education on children in pre-school period: Parental views. Near East University Online Journal of Education, 3(2), 94-103.

Özdoğan, A. Ç., \& Berkant, H. G. (2020). Covıd-19 pandemi dönemindeki uzaktan eğitime ilişkin paydaş görüşlerinin incelenmesi. Milli Eğitim Dergisi, 49(1), 13-43.

Pişirir, N. (2020). Okul öncesi dönemden ilkokula geçişte öğretmenlerin karşılaştı̆̆ sorunların incelenmesi. İstanbul Aydın Üniversitesi Ĕ̆̈itim Fakültesi Dergisi, 6(2), 307-324.

Rice, M. L., \& O'brien, M. (1993). Kansas early childhood research institute on transitions. Final Report. ERIC: ED376641, 303-466. https://files.eric.ed.gov/fulltext/ED376641.pdf

Simsar, A. (2021). An analysis of the views of parents with preschool children in relation to science and preschool science activities. International Journal of Research in Education and Science, 7(2), 383-399.

Skalická, V., Belsky, J., Stenseng, F., \& Wichstrøm, L. (2015). Preschool-age problem behavior and teacherchild conflict in school: Direct and moderation effects by preschool organization. Child Development, 86(3), 955-964.

Sönmez, M., Yıldırım, K., \& Çetinkaya, F. Ç. (2020). Yeni tip Koronavirüs (SARS-CoV2) salgınına bağlı uzaktan eğitim sürecinin sınıf öğretmenlerinin görüşleriyle değerlendirilmesi. Turkish Studies, 15(6), 855-875.

Şentürk, H. (2020). Milli eğitimde DYK kurslarının uzaktan eğitim yoluyla yürütülmesine yönelik incelenmesi. Anadolu Üniversitesi Ĕ̆itim Fakültesi Dergisi, 4(1), 50-66.

Tarlakazan, E., \& Tarlakazan, B. E. (2020). Covid 19 pandemi sürecinde Türkiye' de uzaktan eğitim çalışmaları: Kastamonu Üniversitesi örneği. Electronic Turkish Studies, 15(7), 3107-3122.

Türker, A., \& Dündar, E. (2020). Covid-19 Pandemi sürecinde Eğitim Bilişim Ağı (EBA) üzerinden yürütülen uzaktan eğitimlerle ilgili lise öğretmenlerinin görüşleri. Milli Eğitim Dergisi, 49(1), 323-342.

Vecchia, L. D. (2011). Preschool through first grade transition interventions: Teachers' perceptions of the impact on students (Yayımlanmamış doktora tezi). Wilmington University, Wilmington.

Xie, Z., \& Yang, J. (2020). Autonomous learning of elementary students at home during the COVID-19 epidemic: A case study of the Second Elementary School in Daxie, Ningbo, Zhejiang Province, China. Best Evidence of Chinese Education, 4(2), 535-541.

Yalçın, V., \& Simsar, A. (2020). Adjustment of Syrian refugee children into preschool education in Turkey. Elementary Education Online, 19, 1214-1224.

Yazıc1, D., Nazik Kumbasar, A., \& Akman, B. (2016). Ailelerin gözünden okul öncesinden ilkokula geçişte yaşanan güçlükler ve çözüm önerileri. Ö. Demirel S. Dinçer (Ed.), Ĕ̆gitim bilimlerinde yenilikler ve nitel arayışı (s. 448-458) içinde. Ankara: Pegem Akademi.

Yıldırım, A., \& Simsek, H. (2018). Sosyal bilimlerde nitel araştırma yöntemleri. Ankara: Seçkin Yayıncllık.

Yılmaz, E., Güner, B., Mutlu, H., \& Arın Yılmaz, D. (2020). Farklı öğrenim kademelerindeki öğrencilere verilen uzaktan eğitim hizmetinin veli görüşlerine göre değerlendirilmesi. Milli Ĕ̆itim Dergisi, 49(1), 477-503. 


\section{EXTENDED ABSTRACT}

\section{Introduction}

The prevalence of the SAR-CoV-2 virus, which appeared in the People's Republic of China in December2019 with an unknown cause, increased significantly in January 2020 and began to be seen in various countries. Upon this, the World Health Organization announced that the virus has spread to countries of the world and has turned into an epidemic (pandemic) globally (WHO, 2020). As in the world, various changes have been made in the field of education in Turkey due to the pandemic. Since the first case was seen, education was suspended for a short time, but on March 23, 2020, the Ministry of National Education (MEB) announced that face-to-face education was interrupted for an indefinite period, to prevent children from falling behind in education. (Özdoğan \& Berkant, 2020). With the transition of all levels to distance education, MoNE shared several distance education practices with teachers, students, and parents. With the completion of the 20192020 academic year with distance education, the 2020-2021 academic year is mainly continued with distance education due to pandemic conditions. However, the rapid and unexpected change experienced due to the pandemic affected all stakeholders of education. When this process is considered in the context of early childhood education, some of the students who attended pre-school education at the beginning of the pandemic completed the period with distance education and went through the transition to primary school. Even though children who started primary school in the first grade during the pandemic period participated in face-to-face education at certain intervals, they spent most of the 2020-2021 academic year with distance education. However, it is emphasized that the transition from pre-school education to primary school affects students' future behavior and success (Dockett \& Perry, 2001). Studies have shown that students who have difficulties in the first year of school also experience various problems in other years (Rice \& O'Brien, 1993). For this reason, children must not face various obstacles during the pandemic process due to the completion of preschool education and the transition to primary school through distance education. This study focuses on the life of students who have completed pre-school education and transferred to primary school during the pandemic process. In this direction, the opinions of the parents of the students about the transition to primary school through distance education were investigated.

\section{Methods}

This research is designed as a case study, which is a qualitative research type. Within the scope of the study, it was examined that children completed pre-school education and transition to primary school through distance education during the pandemic period. The study group of the research consisted of 20 parents. The parents of students who have attended pre-school education through distance education during the pandemic period, and also continue their first-grade education, were included in the study. Volunteering was prioritized, and the participants were reached through snowball sampling, and data were collected. A semi-structured interview form was used to collect data in the study. The questions aimed to learn the parents' views during the transition from preschool to primary school with distance education during the pandemic process.

\section{Results}

It was found that in preschool education, mostly teachers sent activities over the phone, and their parents used their activities. Some parents did not find distance education in preschool to be beneficial and stated that the duties of the family increased during this process and that their children had various communication, educational and social problems. Parents recommended live lessons, support to the family, more effective communication, and co-education to make this process more effective. At the beginning of primary school, EBA (Education Information Network) and Zoom applications were used the most, and the TRT School channel was preferred at least in the distance education process. Parents determined the TRT School channel as beneficial in keeping track of lessons and topics, as well as insufficient content, lack of communication, and various problems related to lectures. Besides, the EBA application was preferred by the parents as it contained activities that were sent by the teacher or that belonged to the application. Although there were some technical and educational problems, parents were satisfied with the EBA application. The Zoom was another software used in distance education by the parents. According to the parents, Zoom provided peer interaction, effective 
communication, and measurement, easy access, connection with the school, live lessons, create virtual classrooms. On the other hand, it was found that some parents experienced various technical difficulties and encountered various problems related to usage. Zoom application was mostly satisfied by the parents but it was claimed necessity of improvement in technical terms and various aspects such as language options.

\section{Conclusion}

This study investigated the process of children's transition to primary education through distance education. The study showed that there was limited support provided to parents while children were at the preschool level at the beginning of the pandemic. In primary education, the parents used different digital platforms for different purposes during distance education. They mentioned positive and negative issues regarding the platforms they used. Besides, parents underlined more effective communication between teachers and children as a key issue for children's successful transition to primary school through distance education. Therefore, this study emphasizes the significant role of the teacher during distance education. 